\title{
BIBLIOGRAPHY OF WALT WHITMAN'S \\ SHORT FICTION IN PERIODICALS
}

\section{Introductory Notes:}

The following bibliography is not a complete listing of Walt Whitman's short fiction titles. I have included only the titles of those pieces for which there are newly discovered reprints and/or for which there is the potential for new information about the original, in the case of "Lingave's Temptation" and the stories Whitman would later title "Little Jane" and "The Boy-Lover." Whitman's longer fiction works, namely his novel Franklin Evans, or the Inebriate: A Tale of the Times and "ArrowTip" (later, "The Half-Breed; A Tale of the Western Frontier") are also omitted from the bibliography. I have included a section at the end of this project for reprints of a short story, titled "The Little Minstrel Girl-A Tale of Truth," that has been previously attributed to Whitman.

All entries presented here include standard bibliographical information in addition to a city of publication when possible. Some periodicals use Roman numerals to indicate the "volume" and/or the "number" of an issue; all of these have been converted to standard numbers in order to ensure consistency in numbering throughout the bibliography. If the work is available in a periodicals database or in another electronic form, the name of that database or electronic source is included in the citation. Full citations are provided for previously discovered reprints of Whitman's fiction in periodicals. Previously unknown reprints in periodicals are indicated with circular bullet points. In some cases, newspaper editors divided a single short story by Whitman to create a two-part serial that was printed in consecutive issues of the paper. If the serial divisions occurred within a previously unknown reprint, then each installment is marked with a circular bullet point. Each complete story regardless of the number of serial parts is only counted as one reprint in the list of totals at the end of each section.

Entries are organized both by the title of the short fiction work and chronologically according to the date of publication. If more than one newspaper or magazine printed the same short story on a specific day, then those citations appear in alphabetical order according to the periodical title. If a work was published under more than one title, then each title has its own set of bibliographical entries. I have also included citations for reprints of Whitman's fiction in international periodicals. For each title that has been reprinted outside of the United States, there is a list of citations under the heading of "International Reprints" at the end of the section of the bibliography devoted to that work of fiction.

Under some entries I have included annotations that document key features of a story, such as the reprinting of a particular version of 
an ending, the presence of an epigraph, or the printing of illustrated versions of Whitman's tales. I have only included these notes for the reprints that I was able to view directly online, in a periodical database, or in another form. Some databases require subscriptions to view the full text of an article; in those cases, I have provided as much information as possible, in the sections of the bibliography labeled "Additional reprints in part or in whole for which only partial citation information is available." I have also included notes such as "Preview Only" or "Citation Only" when I have identified a story as Whitman's on the basis of a preview of a small selection from the reprint or when a library's holdings include a reprint of Whitman's fiction that does not appear to be available for viewing in full online.

\section{"Death in the School-Room. A Fact" (Item E 29, Myerson 1993, pg. 544) ${ }^{45}$}

The annotations in the following section document the presence or absence of particular words or sentences and variations in the spelling of names from the original beginning and/or ending. They do not account for every possible variation or editorial change in punctuation or capitalization in the body or even at the end of the story. For example, in the final sentence of this story, some reprints include the hyphenated term "school-room," while others omit the hyphen between the two words. Likewise, some reprints retain the original capitalization of "CORPSE," while others do not; some retain the original punctuation, ending the final sentence with a period, while in some versions, the period has been replaced with an exclamation point. A detailed account of these variations based on comparisons between the first printing and the reprinted versions, in other words, would be a project in its own right.

A list of all the titles that reprint a particular version of the story's ending can be found following the bibliography entries for this title. I have also included notes to indicate when a full-text electronic version of the story was illegible and/or was not readily accessible or available for examination.

\section{ORIGINAL:}

W. W. "DEATH IN THE SCHOOL-ROOM. A FACT.” The United States Magazine, and Democratic Review 9.38 (August 1841): 177-181. [New York, NY]. American Periodicals Series Online 1740-1900. ${ }^{46}$

The original ending includes two sentences that were omitted from the Brooklyn Daily Eagle version, which was published on December 24, 1847, and, later, in other periodicals that reprinted the story from the Eagle.

The original concludes: "The widow was now childless too. Death was in the school-room, and Lugare had been flogging A CORPSE." 
- W. W. "From the Democratic Review. DEATH IN THE SCHOOLROOM. A FACT." Daily Troy Budget 46.27 (August 5, 1841, Evening): [2]. [Troy, NY]. Fulton History.

- W. W. "[From the Democratic Review.] DEATH IN THE SCHOOL-ROOM. A FACT." Albany Evening fournal 12.3554 (August 6, 1841, Evening): [2]. [Albany, NY]. America's Historical Newspapers, including Early American Nerwspapers Series 1 and 2, 1690-1900 and Selected Titles from Series 3, 4, and 5, 1783-1922. (See Early American Newspapers, Series 5). ${ }^{47}$

- W. W. "MISCELLANY. From the Democratic Review DEATH IN THE SCHOOL-ROOM. A FACT." The Norfolk Democrat 3.27, Whole No. 131 (August 6, 1841): [1]. [Dedham, MA]. America's Historical Newspapers, including Early American Newspapers Series 1, 2, 3, 6 and 7, 1690-1922 and African American Newwspapers, 1827-1998. (See Early American Newspapers, Series 6). ${ }^{48}$

"From the Democratic Review. DEATH IN THE SCHOOL-ROOM. A FACT." Salem Gazette 55.63 (August 6, 1841): [1]. [Salem, MA]. America's Historical Newwspapers, including Early American Newspapers Series 1, 2, 3, 6 and 7, 1690-1922 and African American Newspapers, 1827-1998. (See Early American Newspapers, Series 3). ${ }^{49}$

This reprint begins with "Tink-a-ling-ling-ling" rather than the original "Ting-a-ling-ling-ling."

- W. W. "From the Democratic Review. DEATH IN THE SCHOOL-ROOM. A FACT." The Madisonian 4.123, Whole No. 674 (August 7, 1841): [1]. [Washington City (Washington, D. C.)]. America's Historical Newspapers, including Early American Newspapers Series 1, 2, 3, 6 and 7, 1690-1922 and African American Newspapers, 1827-1998. (See Early American Newspapers, Series 3, listed as Madisonian for the Country). ${ }^{50}$

W. W. "From the Democratic Review, for August. DEATH IN THE SCHOOL-ROOM. A FACT." The Long-Island Farmer and Queens County Advertiser 11.17 (August 10, 1841): [1]. [Jamaica, NY]. Fulton History. ${ }^{51}$

- "From the Democratic Review for August. DEATH IN THE SCHOOLROOM. A FACT." Spirit of the Times n. s. 12.7 (August 10, 1841): [1-2]. [Batavia, NY]. Fulton History.

- W. W. "[From the Democratic Review.] DEATH IN THE SCHOOLROOM. A FACT." The Sun No. 2459 (August 10, 1841): [4]. [New York, NY]. Fulton History.

In the final sentence of this reprint, the schoolmaster's name "Lugare" is spelled "Luguare": "Death was in the school room, and Luguare had been flogging a corpse!" 
- W. W.? [Illegible]. "FROM THE DEMOCRATIC REVIEW. DEATH IN THE SCHOOL ROOM. A FACT." Oswego County Whig 4.33 (August 11, 1841): [1]. [Oswego, NY]. Fulton History. ${ }^{52}$

The ending of "Death in the School Room. A Fact." is largely illegible on this particular scan of the reprint.

- W. W. "From the Democratic Review. DEATH IN THE SCHOOL ROOM. A FACT." Manufacturers and Farmers Fournal and Providence and Pawtucket Advertiser 22.54 (August 12, 1841): [2]. [Providence, RI]. Google Nerws Archive Search (Full Text Available). <http://news.google.com/news/ advanced_news_search?as_drrb $=a>.53$

- W. W. "From the Democratic Review. DEATH IN THE SCHOOL ROOM. A FACT." The Cleveland Daily Herald 6.287 (August 13, 1841): [3], col A. [Cleveland, OH]. 19th Century U. S. Nerwspapers. Gale Databases. ${ }^{54}$

- "Miscellany. From the Democratic Review. DEATH IN THE SCHOOLROOM. A FACT." American Masonic Register and Literary Companion 2.50 (August 14, 1841): 394-395. [Albany, N. Y.]. American Periodicals Series Online 1740-1900.

- W. W. "Miscellaneous Selections. From the Democratic Review. Death in the School Room; A FACT." The Hartford Times 25.1286 (August 14, 1841): [1]. [Hartford, CT]. Google News Archive Search (Full Text Available).

- "From the Democratic Review. DEATH IN THE SCHOOL ROOM. A FACT." Haverhill Gazette 22.7 (August 14, 1841): [1]. [Haverhill, MA]. America's Historical Newspapers, including Early American Newspapers Series 1, 2, 3, 6 and 7, 1690-1922 and African American Nezwspapers, 1827-1998. (See Early American Newspapers, Series 1).

- W. W. "From the Democratic Review. DEATH IN THE SCHOOL-ROOM. A FACT." Republican Advocate 30.32 (August 17, 1841): [1]. [Batavia, NY]. Fulton History.

- W. W. "From the Democratic Review. Death in the School Room. A FACT." Rochester Republican 25.34 (August 17, 1841): [4]. [Rochester, NY]. Fulton History.

- W. W. "[From the Democratic Review] DEATH IN THE SCHOOL ROOM. A FACT." The Utica Observer 25.1283 (August 17, 1841): [1-2]. [Utica, NY]. Fulton History.

- "MISCELlANEOUS. From the Democratic Review. Death in the School Room. A FACT." Vermont Gazette 61.3992; n.s.12.33 (August 17, 1841): [4]. [Bennington, VT]. America's Historical Nezwspapers, including Early American Newspapers Series 1 and 2, 1690-1900 and Selected Titles from Series 3, 4, and 5, 1783-1922. (See Early American Newspapers, Series 5).

- W. W. "From the Democratic Review. Death in the School-Room. A FACT." Auburn fournal and Advertiser 9.15 (August 18, 1841): [1]. [Auburn, Cayuga Co., NY]. America's Historical Newspapers, including Early 
American Newspapers Series 1, 2, 3, 6 and 7, 1690-1922 and African American Newspapers, 1827-1998. (See Early American Newspapers, Series 6).

- "From the Democratic Review. Death in the School-Room. A FACT." The Fredonia Censor 21.23, Whole No. 1063 (August 18, 1841): [1]. [Fredonia, Chautauque Co., NY]. Fulton History.

- W. W. "Miscellany. DEATH IN THE SCHOOL-ROOM. A FACT." Perry Democrat 1.34 (August 18, 1841): [1]. [Perry, Wyoming Co., NY]. Fulton History.

- W. W. "[From the Democratic Review.] Death in the School Room. A FACT." The Democratic Expounder and Calhoun County Patriot 5.37, Whole No. 245 (August 19, 1841): [1]. [Marshall, MI]. NewspaperARCHIVE. Access NewspaperARCHIVE. <newspaperarchive.com>; <access.newspaperarchive.com $>.55$

- W. W. "FROM THE DEMOCRATIC REVIEW. DEATH IN THE SCHOOL-ROOM. A FACT." The Pittsfield Sun 42.2135 (August 19, 1841): [1]. [Pittsfield, MA]. America's Historical Newspapers, including Early American Newspapers Series 1, 2, 3, 6 and 7, 1690-1922 and African American Newspapers, 1827-1998. (See Early American Newspapers, Series 1).

- W. W. "From the Democratic Review. DEATH IN THE SCHOOLROOM. A FACT." Skaneateles Columbian 11.11, Whole No. 531 (August 20, 1841): [1]. [Skaneateles, NY]. Fulton History.

"TALES OF REAL LIFE. DEATH IN THE SCHOOL-ROOM.-A FACT." The New-York Mirror: A Weekly Gazette of Literature and the Fine Arts 19.34 (August 21, 1841): 266-267. [New York, NY]. American Periodicals Series Online 1740-1900. ${ }^{56}$

- "Selected Miscellany. From the Democratic Review. DEATH IN THE SCHOOL ROOM. A FACT." The Rochester Gem and Ladies' Amulet 13.17 (August 21, 1841): 136. [Rochester, NY]. American Antiquarian Society Historical Periodicals Collection: Series 3. EBSCOhost. ${ }^{57}$

- "From the Democratic Review. DEATH IN THE SCHOOL ROOM. A FACT.” Rutland Herald 47.34 (August 24, 1841): [1]. [Rutland, VT]. Library of Congress. Chronicling America: Historic American Newspapers. $<$ http://chroniclingamerica.loc.gov/>. ${ }^{58}$

- W. W. "From the Democratic Review. Death in the Schoolroom. A FACT." Wayne County Record 1.37 (August 25, 1841): [1]. [Centreville, Wayne County, IN]. NewspaperARCHIVE.

Although the Wayne County Record cites the Democratic Review, the paper prints a slightly edited version of the ending. Here, the last sentences read, "The widow was now childless indeed. Death was in the school-room, and Lugare had been flogging A CORPSE" [1]. 
- W. W. "DEATH IN THE SCHOOL ROOM. A FACT." The Nerw-England Weekly Review 14.35, Whole No. 703 (August 28, 1841): [1-2], col. G. [Hartford, CT]. $19^{\text {th }}$ Century U. S. Newspapers.

- W. W. "MISCELLANY. From the Democratic Review. DEATH IN THE SCHOOL-ROOM. A FACT." Roman Citizen 2.12 (August 31, 1841): [1]. [Rome, NY]. Fulton History.

- W. W. "From the Democratic Review. DEATH IN THE SCHOOLROOM. A FACT." Green Mountain Emporium 1.3 (September 1841): 13-16. [Middlebury, VT?]. AAS Historical Periodicals Collection: Series 3.

W. W. "DEATH IN THE SCHOOL-ROOM. A FACT." Ladies' Garland and Family Wreath Embracing Tales, Sketches, Incidents, History, Poetry, Music, etc. 5.3 (September 1841): 73-75. [Philadelphia, PA]. American Periodicals Series Online 1740-1900. ${ }^{59}$

This reprint includes the last two sentences of the original ending with a slight editorial change, replacing "The widow was now childless too" with "The widow was now childless indeed" (75).

- W. W. "From the Democratic Review. Death in the School Room. A FACT." Feffersonian Republican 2.27 (September 1, 1841): [1]. [Stroudsburg, Monroe County, PA.]. Library of Congress. Chronicling America.

- W. W. "From the Democratic Review. DEATH IN THE SCHOOL ROOM. A FACT." The fournal 6.37, Whole No. 297 (September 1, 1841): [1]. [Huntingdon, PA]. Huntingdon County Historical Newspaper Collection. Access Pennsylvania Digital Repository. Juniata College. Huntingdon County Historical Newspaper Collection. < http://www.accesspadr.org/cdm4/browse. php? CISOROOT $=\% 2$ Fajuncnews $>.{ }^{60}$

- "MISCELLANEOUS [From the Democratic Review] DEATH IN THE SCHOOL- ROOM A FACT." The Telegraph 15.70 (September 1, 1841): [1]. [Gloucester, MA]. America's Historical Newspapers, including Early American Newspapers Series 1, 2, 3, 6 and 7, 1690-1922 and African American Nezwspapers, 1827-1998. (See Early American Nezwspapers, Series 6, listed as the Gloucester Telegraph). ${ }^{61}$

This newspaper is published on Wednesdays and Saturdays. This is the Wednesday, September 1, 1841, edition. "Death in the School Room" is also printed on the front page of the Saturday, September 4, 1841, edition.

This reprint begins with "Tink-a-ling ling-ling!" rather than the original "Ting-a-ling-ling-ling!"

- "MISCELLANY. From the Democratic Review. DEATH IN THE SCHOOL-ROOM. A FACT." Wisconsin Enquirer 3.40 (September 1, 1841): [1]. [Madison, WT (WI)]. NerwspaperARCHIVE.

The masthead on this paper indicates a date of "August 25, 1841," which has been crossed out and replaced by "September 1, 1841" on this scanned version. The "Number" has also been changed from "XXXIX?" to "XL." 
I have included the "September 1, 1841" date because it is the one that has been assigned to this issue by the database; the issue cited here does differ in content from the previous week's "August 25, 1841" edition of the paper.

- W. W. "Miscellany. [From the Democratic Review.] Death in the SchoolRoom. A FACT." Scioto Gazette 42, Whole No. 2138, Present Series 7.21 (September 2, 1841): [1], col. B. [Chillicothe, OH]. 19 $9^{\text {th }}$ Century U. S. Nerwspapers.

- W. W. "From the Democratic Review. DEATH IN THE SCHOOL ROOM. A FACT." Goshen Democrat 4.21, Whole No. 177 (September 2, 1841): 1-2. [Goshen, IN]. NewspaperARCHIVE.

- W. W. "[From the Democratic Review.] DEATH IN THE SCHOOL-ROOM. A FACT." The Indiana fournal 19.1003 (September 3, 1841): [4], col. A. [Indianapolis, IN]. 19 $9^{\text {th }}$ Century U. S. Newspapers.

- W. W. "From the Democratic Review. DEATH IN THE SCHOOL ROOM. A FACT." Kalamazoo Gazette 8.382 (September 3, 1841): 1. [Kalamazoo, MI]. America's Historical Newspapers, including Early American Newspapers Series 1, 2, 3, 6 and 7, 1690-1922 and African American Newwspapers, 18271998. (See Early American Newspapers, Series 6).

The full-text of this reprint was unavailable.

- "MISCELLANEOUS. [From the Democratic Review.] DEATH IN THE SCHOOL-ROOM. A FACT." The Telegraph 15.36 (September 4, 1841): [1]. [Gloucester, MA]. America's Historical Newspapers, including Early American Newspapers Series 1, 2, 3, 6 and 7, 1690-1922 and African American Newspapers, 1827-1998. (See Early American Nezwspapers, Series 6, listed as the Gloucester Telegraph).

This newspaper is published on Wednesdays and Saturdays. This is the Saturday, September 4, 1841, edition. "Death in the School Room" is also printed on the front page of the Wednesday, September 1, 1841, edition.

This reprint begins with "Tink-a-ling ling-ling!" rather than the original "Ting-a-ling-ling-ling!"

- "From the Democratic Review. DEATH IN THE SCHOOL ROOM. A FACT." The Neapolitan 2.15 (September 9, 1841): [1-2]. [Naples, Ontario, Co., NY]. Fulton History.

- W. W. "MISCELLANY. From the Democratic Review. DEATH IN THE SCHOOL ROOM. A FACT." New-Hampshire Patriot and State Gazette 32.1683; New Series, 7.353 (September 9, 1841): [4]. [Concord, NH]. America's Historical Newspapers, including Early American Newspapers Series 1, 2, 3, 6 and 7, 1690-1922 and African American Newspapers, 1827-1998. (See Early American Newspapers, Series 1).

- "From the Democratic Review. DEATH IN THE SCHOOL ROOM. A FACT." Barre Gazette 8.18, Whole No. 382 (September 10, 1841): [1]. [Barre, MA]. America's Historical Newspapers, including Early American 
Newspapers Series 1, 2, 3, 6 and 7, 1690-1922 and African American Newspapers, 1827-1998. (See Early American Newspapers, Series 1).

- W. W. "From the Democratic Review. DEATH IN THE SCOOL-ROOM. A FACT." [sic.] Sunbury American and Shamokin fournal 1.50 (September 11, 1841): [1]. [Sunbury, Northumberland Co., PA]. Library of Congress. Chronicling America.

- "MISCELLANY. DEATH IN THE SCHOOL-ROOM. A FACT." Mohawk Courier 8.12 (September 16, 1841): [1]. [Little Falls, NY]. Fulton History.

- "From the Democratic Review. Death in the School Room. A FACT." The Illinois Free Trader and LaSalle County Commercial Advertiser 2.17 (September 17, 1841): [1]. [Ottawa, IL]. Library of Congress. Chronicling America.

- "MISCELLANY. From the Democratic Review, for August. DEATH IN THE SCHOOL-ROOM. A FACT." Austin City Gazette 2.46 (September 22, 1841): 1. [City of Austin, TX]. America's Historical Newspapers, including Early American Newspapers Series 1 and 2, 1690-1900 and Selected Titles from Series 3, 4, and 5, 1783-1922. (See Early American Nerwspapers, Series $4)$.

- W. W. "From the Democratic Review. DEATH IN THE SCHOOL ROOM. A FACT." The Macon Georgia Telegraph 16.1 (October 5, 1841): [2]. [Macon, GA]. America's Historical Newspapers, including Early American Nerwspapers Series 1, 2, 3, 6 and 7, 1690-1922 and African American Nezwspapers, 18271998. (See Early American Newspapers, Series 2, listed as the Macon Weekly Telegraph). ${ }^{62}$

- W. W. "From the Democratic Review. DEATH IN THE SCHOOL ROOM. A FACT." The Western Argus n.s. 1.26, Whole No. 515 (October 20, 1841): [1]. [Lyons, NY]. Fulton History.

"Death in the School-Room (a Fact)." The Mauch Chunk Courier (October, 25, 1841): 1. [Mauch Chunk, PA] . ${ }^{63}$

- "DEATH IN THE SCHOOL ROOM. A FACT." Skaneateles Democrat 12.51, Whole No. 624 (December 19, 1851): [1]. [Skaneateles, NY]. Fulton History.

- "A Thrilling Story. DEATH IN THE SCHOOL-ROOM. A FACT." Edgefield Advertiser 17.35 (September 15, 1852): [1]. [Edgefield, SC]. Library of Congress. Chronicling America. ${ }^{64}$

The story is printed in a column with the heading: "A Thrilling Story." At the end of the story, the editor has listed what is presumably the source of the story as "-Correspondence Richmond Magnolia," perhaps indicating the presence of another reprint in that paper.

- "Death in the school room. A FACT." Barre Gazette 20.12, Whole No. 1002 (September 23, 1853): [1-2]. [Barre, MA]. America's Historical Newspapers, 
including Early American Nezwspapers Series 1, 2, 3, 6 and 7, 1690-1922 and African American Newwspapers, 1827-1998. (See Early American Newspapers, Series 1).

- "Miscellaneous. DEATH IN THE SCHOOL-ROOM. A FACT." Barnstable Patriot 24.16 (October 11, 1853): [1]. [Barnstable, MA]. Sturgis Library. Barnstable Patriot Digital Newwspaper Archive.

$<$ http://apa.olivesoftware.com/Default/Skins/Sturgis/Client. asp? Skin $=$ Sturgis $\&$ AppName $=2>.{ }^{65}$

- "DEATH IN THE SCHOOL ROOM. A FACT." The National Aegis, Third Series. 16.43, Whole No. 2296. (November 16, 1853): 1. [Worcester, MA]. America's Historical Newspapers, including Early American Newspapers Series 1, 2, 3, 6 and 7, 1690-1922 and African American Newspapers, 1827-1998. (See Early American Newspapers, Series 7).

- W. W. "Death in the School-Room. A FACT." The Lancaster Intelligencer 64.13 (April 7, 1863): [1]. [Lancaster City, PA]. Pennsylvania Civil War Newspapers. Penn State University Libraries.

$<$ http://digitalnewspapers.libraries.psu.edu/Default/Skins/civilwar/Client. asp? skin $=$ civilwar $\& A W=1341094627037 \&$ AppName $=2>.{ }^{66}$

This newspaper - published some fifteen years after Whitman stopped writing fiction and approximately four months after he left Pfaff's for Virginia and eventually the Civil War hospitals - actually prints two of Whitman's stories in the same issue. "Death in the School-Room" and the temperance tale "Wild Frank's Return" both appear on the front page of the paper.

- W. W. "DEATH IN THE SCHOOL-ROOM. A FACT." Clearfield Republican 33.1755; n.s. 53.40 (April 15, 1863): [1]. [Clearfield, PA]. Pennsylvania Civil War Newspapers. Penn State University Libraries.

- W. W. "Select Sketch. Death in the School-Room. A FACT." Columbia Democrat and Bloomsburg General Advertiser 17.10, Volume 27 (May 9, 1863): [1]. [Bloomsburg, Columbia County, "PENN'A" (PA)]. Chronicling America. Library of Congress.

ALSO REPRINTED AS:

\section{"Death in the School Room"}

- W. W. "From the Democratic Review. DEATH IN THE SCHOOLROOM." Ohio Atlas and Elyria Advertiser 10.16 (September 1, 1841): [1]. [Elyria, Lorain County, OH]. NewspaperARCHIVE.

- "[From the Democratic Review.]. DEATH IN THE SCHOOL ROOM." The Experiment 7.4, Whole No. 316 (September 8, 1841): [1]. [Norwalk, Huron County, OH]. NewspaperARCHIVE. 
Whitman, Walter. "Death in the school room." The Brooklyn Daily Eagle and Kings County Democrat 6.304 (December 24, 1847): [1]. [Brooklyn, NY]. Brooklyn Daily Eagle Online 1841-1902.

$<$ http://eagle.brooklynpubliclibrary.org/Default/Skins/BEagle/Client. asp? Skin $=$ Beagle $>.{ }^{67}$

The last two sentences of the original story are omitted in the Brooklyn Daily Eagle version such that the ending reads, "The boy was dead! He had probably been so for some time, for his eyes were turned up, and his body was cold" [1].

- Whitman, Walter. "DEATH IN THE SCHOOL ROOM." The New Hampshire Gazette and Republican Union 94.8 (February 22, 1848): [1]. [Portsmouth, NH]. America's Historical Newspapers, including Early American Newspapers Series 1, 2, 3, 6 and 7, 1690-1922 and African American Newspapers, 1827-1998. (See Early American Newspapers, Series 3, listed as the New-Hampshire Gazette). ${ }^{68}$

The New Hampshire Gazette omits the final two sentences that had appeared in the Democratic Review, just as The Brooklyn Daily Eagle and Kings County Democrat did when it reprinted the story on December 24, 1847.

ALSO REPRINTED AS:

\section{"Death in a School Room. A Fact."}

- "MISCELLANY. [From the Democratic Review for August.]. DEATH IN A SCHOOL ROOM.-A FACT." New-Bedford Register 3.29 (August 11, 1841): [2]. [New Bedford, MA]. America's Historical Newspapers, including Early American Newspapers Series 1, 2, 3, 6 and 7, 1690-1922 and African American Nerwspapers, 1827-1998. (See Early American Newspapers, Series 6).

- "From the Democratic Review. DEATH IN A SCHOOL-ROOM. A FACT." The Broome Republican 19.5 (August 19, 1841): [1-2]. [Binghamton, Broome County, NY]. Fulton History.

- W. W. "From the Democratic Review, for August. DEATH IN A SCHOOL ROOM. A FACT." The Portsmouth Fournal of Literature and Politics 52.34 (August 21, 1841): [1]. [Portsmouth, NH]. America's Historical Newspapers, including Early American Newspapers Series 1 and 2, 1690-1900 and Selected Titles from Series 3, 4, and 5, 1783-1922. (See Early American Newspapers, Series 4).

- "From the Democratic Review, for August. DEATH IN A SCHOOL ROOM. A FACT." Hampshire Gazette 56.1, Whole No. 3043 (August 31, 1841): [1]. [Northampton, Mass.]. America's Historical Newspapers, including Early American Newspapers Series 1 and 2, 1690-1900 and Selected Titles from Series 3, 4, and 5, 1783-1922. (See Early American Newspapers, Series 5). 
- W. W. "Miscellaneous. FROM THE DEMOCRATIC REVIEW. DEATH IN A SCHOOL ROOM. A FACT." The Ohio Repository 31.3, Whole No. 1555 (May 15, 1845): [1]. [Canton, Stark County, OH]. NezwspaperARCHIVE.

Whitman, Walter. "Death in a School-Room [From the Democratic Review]." Southern Literary Gazette: An Illustrated Weekly fournal of BellesLettres, Science and the Arts (March 3, 1849). [Athens, GA]. (Citation Only). ${ }^{69}$

- W. W. "Death in a School-room. A FACT." Chittenango Phenix 4.31, Whole No. 187 (July 7, 1852): [1]. [Chittenango, Madison Co, N.Y.]. Fulton History.

The Chittenango Phenix acknowledges the "Dem. Review" as the source of the story, but offers a slightly altered version of the ending, printing "The widow was now childless" instead of the original "the widow was now childless too."

- W. W. "Miscellany. DEATH IN A SCHOOL-ROOM. A FACT." Onondaga Gazette 6.37, Whole No. 297 (July 22, 1852): [1]. [Baldwinsville, NY]. Fulton History.

The Onondaga Gazette acknowledges the "Dem Review" as the source of the story, but offers a slightly altered version of the ending, printing "The widow was now childless" instead of the original "the widow was now childless too."

- W. W. "Death in a School-Room: A Fact." Fayetteville Observer 2.30 (August 19, 1852): 1. [Fayetteville, TN]. Chronicling America. Library of Congress.

The Fayetteville Observer prints the ending as "The widow was now childless.- Death was in the school room; and Lugare had been flogging $a$ corpse."

- W. W. "DEATH IN A SCHOOL ROOM. A FACT." The Peru Free Press 1.4 (November 23, 1852): 1. [Peru, Indiana]. NewspaperARCHIVE.

The Peru Free Press prints a slightly edited ending of the story: "The widow was now childless. Death was in the school Room, and Lugare had been flogging a CORPSE."

This paper also prints an altered beginning of the story; instead of "Ting a-ling-ling-ling!" the tale begins with "Ring a-ling-ling-ling!"

ALSO REPRINTED AS:

\section{"Death in a School-Room"}

- Whitman, W. or Whitman, Walter? [Illegible]. "Death in a School-Room." The Logansport fournal 1.48 (March 16, 1850): [1]. [Logansport, Cass County, IN]. NewspaperARCHIVE. 
Like the Brooklyn Daily Eagle version of the story, The Logansport fournal reprint omits the last two sentences of the original tale.

- "Death in A School Room." The Prairie Chieftain 3.49 (June 16, 1853): [1]. [Monticello, White County, Ind.]. NewspaperARCHIVE.

This reprint of the story begins with "Ring a-ling-ling-ling!" instead of "Ting a-ling-ling-ling!"

The paper prints the following ending: "The widow was now childless.Death was in the school room, and Lugare had been flogging a corpse" [1].

- "Tales and Sketches. DEATH IN A SCHOOL ROOM." Oneida Chief5.35 (May 9, 1856): [1]. [Clinton, NY]. Fulton History.

- "Death in a School Room." The Lewis County Republican 20.35, Whole No. 1025 (May 21, 1856): [3]. ["Martinsburgh" appears beneath the masthead; listed as "Lowville, NY" in the database]. Fulton History.

ALSO REPRINTED AS:

\section{"Death in a School-Room. A Thrilling Sketch from Life"}

- "Thrilling Sketch from Life. DEATH IN A SCHOOL-ROOM." American Union 15.9 (December 29, 1855): [2]. [Boston, MA]. AAS Historical Periodicals Collection: Series 4.

The American Union reprints "Death in the School-Room. A Fact." as "Death in a School-Room," with the title appearing under the heading, "Thrilling Sketch from Life," so I have chosen to include it here with other reprints where "Thrilling Sketch from Life" follows the title.

- "Death in a School Room. A Thrilling Sketch from Life." Chicago Daily Tribune 9.197 (February 7, 1856): [1]. [Chicago, IL]. ProQuest Historical Newspapers: Chicago Tribune 1849-1989; Chicago Daily Tribune 1847-1858. ${ }^{70}$

- "DEATH IN A SCHOOL ROOM. A Thrilling Sketch from Life." Weekly Wisconsin 9.40 (February 20, 1856): [3]. [Milwaukee, WI]. NerwspaperARCHIVE.

- "DEATH IN A SCHOOL ROOM. A THRILLING SKETCH FROM LIFE." The Kenosha Democrat 5.40 (February 22, 1856): [1]. [Kenosha, WI]. NewspaperARCHIVE.

- "DEATH IN A SCHOOL ROOM. A Thrilling Sketch from Life." Sheboygan Lake fournal 5.15 (February 26, 1856): [1]. [Sheboygan, WI]. NewspaperARCHIVE.

- "DEATH IN A SCHOOL ROOM. A THRILLING SKETCH FROM LIFE." Democratic Standard 5.19 (February 27, 1856): [1]. [Janesville, WI]. NewspaperARCHIVE. 
- "DEATH IN A SCHOOL-ROOM. A Thrilling Sketch From Life." Hornellsville Tribune 5.14, Whole No. 222 (February 28, 1856): 1. [Hornellsville, NY]. NewspaperARCHIVE.

- "Death in a School Room. A THRILLING SKETCH FROM LIFE." Litchfield Republican 9.37, Whole No. 454 (March 7, 1856): 1. [Litchfield, CT]. America's Historical Newspapers, including Early American Newspapers Series 1 and 2, 1690-1900 and Selected Titles from Series 3, 4, and 5, 1783-1922. (See Early American Nerwspapers, Series 5).

- "Miscellany. Death in a School Room. A THRILLING SKETCH FROM LIFE." Madison Observer 35.1787 (May 10, 1856): [4]. [Morrisville, Madison Co., NY]. Fulton History.

- "DEATH IN A SCHOOL ROOM. A THRILLING SKETCH FROM LIFE.” Putnam Republican Banner 4.21 (May 21, 1856): [1]. [Greencastle, IND]. Greencastle Newspapers. Digitizing Greencastle: Newspapers 1837-1974. Depauw University Libraries. Digital Library. ${ }^{71}$

$<$ http://digital.library.depauw.edu/cdm4/search_greencastlenewspapers. php>.

- "DEATH IN A SCHOOL-ROOM. A THRILLING SKETCH FROM LIFE." The Manitowoc Pilot 2.17 (November 2, 1860): [1]. [Manitowoc, WI]. NerwspaperARCHIVE.

ALSO REPRINTED AS:

\section{"A Thrilling Sketch from Life"}

- "A Thrilling Sketch from Life." Superior Chronicle 1.43 (April 1, 1856): [1]. [Superior, Douglas County, WI]. NewspaperARCHIVE.

ALSO REPRINTED AS:

\section{"Death in a School-Room. A Sketch from Life."}

- "Death in a School Room. A SKETCH FROM LIFE." Cedar Falls Gazette 1.16 (June 29, 1860): [1]. [Cedar Falls, IA]. NewspaperARCHIVE.

- "MISCELLANY. Death in a School Room. A SKETCH FROM LIFE." Vermont Patriot 35.28, n.s. No. 756 (July 7, 1860): [4], col. A. [Montpelier, VT]. $19^{\text {th }}$ Century U. S. Nerwspapers.

- "Death in a School Room. A SKETCH FROM LIFE." The Wisconsin Daily Patriot 6.67 (July 13, 1860): [1]. [Madison, WI]. America's Historical Nerwspapers, including Early American Newspapers Series 1, 2, 3, 6 and 7, 1690-1922 and African American Newspapers, 1827-1998. (See Early American Newspapers, Series 3).

The Wisconsin Daily Patriot reprints "Death in the School-Room. A Fact." as "Death in a School Room. A Sketch From Life." and as a work of serial fiction in two installments. 
- "Death in a School Room. A SKETCH FROM LIFE. Concluded." The Wisconsin Daily Patriot 6.68 (July 14, 1860): [1]. [Madison, WI]. America's Historical Newspapers, including Early American Newspapers Series 1, 2, 3, 6 and 7, 1690-1922 and African American Newspapers, 1827-1998. (See Early American Newspapers, Series 3).

This is the second and concluding installment of the story.

- "Death in a School Room. A SKETCH FROM LIFE." Wisconsin Patriot 7.18 (July 21, 1860): [1]. [Madison, WI]. America's Historical Newspapers, including Early American Newspapers Series 1, 2, 3, 6 and 7, 1690-1922 and African American Newspapers, 1827-1998. (See Early American Newspapers, Series 2, listed as the Weekly Wisconsin Patriot). ${ }^{72}$

- "Death in a School Room. A SKETCH FROM LIFE." Fanesville Daily Gazette 4.136 (August 16, 1860): [1]. [Janesville, WI]. NewspaperARCHIVE.

This is the first of two installments of "Death in a School Room." "[Concluded tomorrow.]" appears at the end of the selection printed in this edition.

- "Death in a School Room. A SKETCH FROM LIFE [Concluded]." Fanesville Daily Gazette 4.137 (August 17, 1860): [1]. [Janesville, WI]. NewspaperARCHIVE.

This is the second of two installments of "Death in a School Room."

- "Death in a School Room. A SKETCH FROM LIFE." Weekly Gazette and Free Press 15.52 (August 24, 1860): [1]. [Janesville, WI]. NewspaperARCHIVE.

- "Death in a School Room. A SKETCH FROM LIFE." Beaver Dam Democrat 8.44 (September 1, 1860): [1]. [Beaver Dam, WI]. NezwspaperARCHIVE.

The Beaver Dam Democrat reprint contains a slight variation from the original ending: "The widow was now childless, too.-Death was in the school-room, and Lugare has been flogging a corpse!"

- "Death in a School Room. A SKETCH FROM LIFE." The Waupun Times 5.17 (January 23, 1862): [1]. [Waupun, WI]. NewspaperARCHIVE.

- "Miscellaneous. Death in a School Room. A SKETCH FROM LIFE." Beaver Dam Argus 2.9 (January 31, 1862): [1]. [Beaver Dam, WI]. NewspaperARCHIVE.

ALSO REPRINTED AS:

\section{"Scene in a School. A Fact."}

- "Scene in a School. A Fact." The Greensborough Patriot 3.34 (October 5, 1841): [1]. [Greensborough, NC]. University of North Carolina Greensboro (UNCG) Digital Collections: Greensboro Historical Newspapers. <http:// libcdm.uncg.edu/cdm/landingpage/collection/GSOPatriot $>.{ }^{73}$ 
The Greensborough Patriot acknowledges the "Democratic Review" as the source of the story.

ALSO REPRINTED AS:

"The Widow's Son, - Or- Death in the School-Room."

- “Lessons from Life. THE WIDOW'S SON, - OR- DEATH IN THE SCHOOL-ROOM." The Watch Tower 2.17 (April 29, 1854): 129-130. [Portland, ME]. AAS Historical Periodicals Collection: Series 4.

ADDITIONAL REPRINTS IN PART OR IN WHOLE FOR WHICH ONLY PARTIAL CITATION INFORMATION IS AVAILABLE:

- "[Death in the School-Room. A Fact.]." Boston Traveler (August 3, 1841). [Boston, Massachusetts, 1825-1967]. Historical Newspaper Archives, GenealogyBank. <www.genealogybank.com/gbnk/>. (Preview only without a paid subscription) ${ }^{74}$

- "[Death in the School-Room]." Caledonian (September 14, 1841). [St. Johnsbury, VT]. Historical Newspaper Archives. GenealogyBank.

- "[Death in the School-Room]." Columbus Enquirer (October, 13, 1841): [1-2]. [Columbus, Georgia]. Digital Library of Georgia. Georgia Historic Newspapers: Columbus Enquirer. <http://dlg.galileo.usg.edu/Institutions/ gnp.html?Welcome>.

(Citation Only, Full-text available only with program download). ${ }^{75}$

- ["Death in the School-Room."] Springfield Republican (May 1, 1856). [Springfield, MA]. Historical Newspaper Archives. GenealogyBank.

NUMBER OF REPRINTS OF "Death in the School-Room" (and variant titles): 104

Number of Previously Unknown Reprints in Periodicals Cited Here: 98

All of the following titles reprint the original ending; however, the Scioto Gazette, The Western Argus, The Greensborough Patriot, the Goshen Democrat, the Beaver Dam Democrat, and the Waupun Times add a dash: "The widow was now childless too.--Death was in the school-room, and Lugare had been flogging A CORPSE."

Titles of Newspapers that Reprint the Original Ending: Troy Daily Budget, Albany Evening fournal, The Norfolk Democrat, Salem Gazette, The Madisonian, The Long-Island Farmer and Queens County Advertiser, The NY Sun, Spirit of the Times, Manufacturers and Farmers fournal and Providence and Pawtucket Advertiser, The Cleveland Daily Herald, American Masonic Register and Literary Companion, The Hartford Times, Haverhill Gazette, Republican Advocate, Rochester Republican, The Utica Observer, Vermont Gazette, Auburn fournal and 
Advertiser, The Fredonia Censor, Perry Democrat, Democratic Expounder and Calhoun County Patriot, The Pittsfield Sun, Skaneateles Columbian, The New -York Mirror: a Weekly Gazette of Literature and the Fine Arts, The Rochester Gem and Ladies' Amulet, The New-England Weekly Review, Roman Citizen, Green Mountain Emporium, Feffersonian Republican, Ohio Atlas and Elyria Advertiser, The Fournal, The Telegraph (Wed. edition), Wisconsin Enquirer, Scioto Gazette, Goshen Democrat, The Indiana fournal, The Telegraph (Sat. edition), The Experiment, The Neapolitan, Nerw-Hampshire Patriot and State Gazette, Barre Gazette (1841), Sunbury American and Shamokin fournal, Mohawk Courier, Austin City Gazette, The Macon Georgia Telegraph, The Western Argus, Skaneateles Democrat, Barre Gazette (1853), Barnstable Patriot, The National Aegis, Columbia Democrat and Bloomsburg General Advertiser, New-Bedford Register, Broome Republican, The Portsmouth fournal of Literature and Politics, Hampshire Gazette, The Ohio Repository, American Union, Chicago Daily Tribune, Weekly Wisconsin, Kenosha Democrat, Sheboygan Lake fournal, Democratic Standard, Hornellsville Tribune, Litchfield Republican, Oneida Chief, Madison Observer, The Lewis County Republican, Putnam Republican Banner, Cedar Falls Gazette, Vermont Patriot, The Wisconsin Daily Patriot, Wisconsin Patriot (Weekly), Fanesville Daily Gazette, Weekly Gazette and Free Press, Manitowoc Pilot, The Waupun Times, Beaver Dam Argus, The Lancaster Intelligencer, Clearfield Republican, The Greensborough Patriot, The Watch Tower, the Superior Chronicle, Edgefield Advertiser, The Illinois Free Trader and LaSalle County Commercial Advertiser, and the Rutland Herald

Total Number of Newspapers that Print the Original Ending: 85

Titles of Newspapers that Print the Edited Original Ending, Changing "The widow was now childless too" to "The widow was now childless, indeed.": Wayne County Record and Ladies' Garland and Family Wreath Embracing Tales, Sketches, Incidents, History, Poetry, Music, etc.

Total Number of Newspapers that Print the Edited Ending: 2

Titles of Newspapers that Print the Brooklyn Daily Eagle Ending: The Brooklyn Daily Eagle and Kings County Democrat, The New Hampshire Gazette and Republican Union, and The Logansport fournal (1850)

Total Number of Newspapers that Print the Brooklyn Daily Eagle Ending: 3

Titles of Newspapers that Print an Edited Version of the Original Ending, Changing "Lugare had been flogging a corpse" to "Lugare has been flogging a corpse!": Beaver Dam Democrat

Total Number of Newspapers that Print this Edited Version of the Original Ending: 1

Titles of Newspapers for which Full-Text was Illegible or Unavailable: Oswego County Whig, Kalamazoo Gazette, The Mauch Chunk Courier, Southern Literary 
Gazette: An Illustrated Weekly fournal of Belles-Lettres, Science and the Arts, Caledonian, Columbus Enquirer, the Springfield Republican, and the Boston Traveler.

Total Number of Newspapers for which Full-Text was Unavailable: 8

Titles of Newspapers that Print the Ending as Follows: "The widow was now childless [-]. Death was in the school room." Some papers that omit "too" and "indeed" also include a dash after "childless," namely the Fayetteville Observer and the Prairie Chieftain; the others do not: The Peru Free Press, Fayetteville Observer, Onondaga Gazette, The Prairie Chieftain, Chittenango Phenix

Total Number of Newspapers that Omit "too" or "indeed" After "The widow was now childless": 5

\section{“Wild Frank’s Return” (Item E 30, Myerson 1993, pg. 544)}

\section{ORIGINAL:}

Whitman, Walter. "WILD FRANK'S RETURN." The United States Magazine, and Democratic Review 9.41 (November 1841): 476-482. [New York, NY]. American Periodicals Series Online 1740-1900. ${ }^{76}$

\section{REPRINTS IN PERIODICALS:}

- Whitman, Walter. "From the Democratic Review. WILD FRANK'S RETURN." The North American and Daily Advertiser, Volume 71, Whole No. 20,565; 3.826 (November 20, 1841): [1], col. F. [Philadelphia, PA]. $19^{\text {th }}$ Century US Newspapers; America's Historical Newspapers, including Early American Newspapers Series 1 and 2, 1690-1900 and Selected Titles from Series 3, 4, and 5, 1783-1922. (See Early American Newspapers, Series 4, listed as the North American). ${ }^{77}$

- Whitman, Walter. "WILD FRANK'S RETURN." Daily Troy Budget 48.130 (December 4, 1841, Evening): [2]. [Troy, NY]. Fulton History.

- Whitman, Walter. “[From the Democratic Review] WILD FRANK'S RETURN." Albany Evening fournal 12.3660 (December 8, 1841): [2]. [Albany, NY]. America's Historical Newspapers, including Early American Nezwspapers Series 1 and 2, 1690-1900 and Selected Titles from Series 3, 4, and 5, 1783-1922 (See Early American Newspapers, Series 5); Fulton History.

- Whitman, Walter. "Miscellaneous Wild Frank's Return." Vermont Gazette 61.4,010; n. s. 12.51 (December 21, 1841): [4]. [Bennington, Vermont]. America's Historical Newspapers, including Early American Newspapers Series 1 and 2, 1690-1900 and Selected Titles from Series 3, 4, and 5, 1783-1922. (See Early American Newspapers, Series 5). 
- Whitman, Walter. "From the Democratic Review. WILD FRANK'S RETURN." Northern fournal 4.45 (December 23, 1841): [1]. [Lowville, Lewis Co., NY]. Fulton History.

Whitman, Walter. "From the Democratic Review. WILD FRANK'S RETURN." The Long-Island Farmer and Queens County Advertiser 11.39 (January 11, 1842): [1]. [Jamaica, NY]. Fulton History. ${ }^{78}$

Whitman, W. "A tradition of Long Island, from the 'Democratic Review.' Wild Frank's Return." The Brooklyn Eagle and King's County Democrat 5.113 (May 8, 1846): [2]. [Brooklyn, NY]. Fulton History; Brooklyn Daily Eagle Online, 1841-1902.

- [Whitman, Walter]. "Wild Frank's Return." The Northern Pioneer 1.15 (October 7, 1848): 116. [Portland, ME?]. ("Periodicals and Books Containing Contributions by Whitman Subseries, 1841-1924." Writings Series, 1841-1944 and undated. Inventory of the Trent Collection of Whitmania, 1841-1992, bulk 1845-1849, 1854-1857, and 1864-1892). ${ }^{79}<\mathrm{http}: / /$ library. duke.edu/rubenstein/findingaids/whitmaniana/\#c01_1>

- Whitman, Walter. "Miscellany. WILD FRANK'S RETURN." The SemiWeekly Eagle 2.23, Whole No. 127 (October 26, 1848): [4]. [Brattleboro, Vermont]. America's Historical Newspapers, including Early American Newspapers Series 1, 2, 3, 6 and 7, 1690-1922 and African American Newspapers, 1827-1998. (See Early American Newspapers, Series 1, listed as Weekly Eagle). ${ }^{80}$

- Whitman, Walter. "WILD FRANK'S RETURN.” The Lancaster Intelligencer 64.13 (April 7, 1863): [1]. [Lancaster City, PA]. Pennsylvania Civil War Newspapers. Penn State University Libraries.

This newspaper prints two of Whitman's stories in the same issue. "Death in the School-Room" and the temperance tale "Wild Frank's Return" both appear on the front page of the paper.

- "WILD FRANK'S RETURN." The Cambria Freeman 14.21 (June 11, 1880): [1]. [Ebensburg, PA]. Library of Congress. Chronicling America.

The following note is printed under the title of the story:

[The following thrilling sketch, the main incidents of which were of actual occurrence, is from the pen of the venerable Walt Whitman. It has long been out of print, having been contributed to the Democratic Review of November, 1841.-Editor Shippensburg Chronicle.]

- Whitman, "Walter." "WILD FRANK'S RETURN (From The Eagle, May 8, 1846)." The Brooklyn Daily Eagle (Walt Whitman Centenary Edition, with a 12-page Walt Whitman Section) 79.150 (May 31, 1919): 9-10 (Walt Whitman Section). [Brooklyn, NY]. Fulton History.

NUMBER OF REPRINTS OF "Wild Frank's Return": 12

Number of Previously Unknown Reprints in Periodicals Cited Here: 10 


\section{“The Child's Champion" (Item E 31, Myerson 1993, pg. 544)}

\section{ORIGINAL:}

Whitman, Walter. “Original Tale. THE CHILD'S CHAMPION.” The New World; a Weekly Family fournal of Popular Literature, Science, Art and News 3.21, Whole No. 77 (November 20, 1841): 321-322. [New York, NY]. American Periodicals Series Online 1740-1900. ${ }^{81}$

There are no known reprints of the story in nineteenth century periodicals under this title.

\section{"The Child and the Profligate" (Item E 173, Myerson 1993, pg. 560) ${ }^{82}$}

Whitman significantly revised "The Child's Champion," renaming the story "The Child and the Profligate." It was published for the first time under this new title in the October 1844 issue of The Columbian Lady's and Gentleman's Magazine. ${ }^{83}$

FIRST PRINTING OF THE REVISED “THE CHILD'S CHAMPION” UNDER THE TITLE OF "THE CHILD AND THE PROFLIGATE":

Whitman, Walter, AUTHOR OF “THE MERCHANT'S CLERK." "THE CHILD AND THE PROFLIGATE." The Columbian Lady's and Gentleman's Magazine, Embracing Literature in Every Department: Embellished with the Finest Steel and Mezzotint Engravings, Music, and Colored Fashions (October 1844): 149-153. [New York, NY]. American Periodicals Series Online 1740-1900. ${ }^{84}$

The following epigraph precedes Whitman's short story:

'They say 'tis pleasant on the lip,

And merry on the brain-

They say it stirs the sluggish blood,

And dulls the tooth of pain,

Ay_-but within its gloomy deeps

A stinging serpent, unseen, sleeps.

WILLIS.

REPRINTINGS OF THE REVISED “THE CHILD'S CHAMPION” UNDER THE TITLE "THE CHILD AND THE PROFLIGATE" IN PERIODICALS:

- Whitman, Walter, AUTHOR OF “THE MERCHANT'S CLERK." “THE CHILD AND THE PROFLIGATE." Pennsylvania Inquirer and National Gazette 31.96, Whole No. 3526 (October 21, 1844): [1]. [Philadelphia, PA]. America's Historical Newspapers, including Early American Newspapers Series 1, 2, 3, 6 and 7, 1690-1922 and African American Nezwspapers, 18271998. (See Early American Newspapers, Series 7, listed as the Philadelphia Inquirer). ${ }^{85}$ 
Whitman, Walter. "The Child and the Profligate." The Brooklyn Daily Eagle and Kings County Democrat 6.22 (January 27, 1847): [1]. [Brooklyn, NY]. Brooklyn Daily Eagle Online 1841-1902.

$<$ http://eagle.brooklynpubliclibrary.org/Default/Skins/BEagle/Client. asp? Skin $=$ Beagle $>.{ }^{86}$

The Columbian magazine version of the story underwent minor revisions before being published in the Brooklyn Daily Eagle, where it was printed as a work of serial fiction that ran for three days, January 27-29, 1847. ${ }^{87}$

The epigraph is not included in the Brooklyn Daily Eagle.

Whitman, Walter. "The Child and the Profligate [Continued]." The Brooklyn Daily Eagle and Kings County Democrat 6.23 (January 28, 1847): [1]. [Brooklyn, NY]. Brooklyn Daily Eagle Online 1841-1902.88

This is the second installment - the continuation-of "The Child and the Profligate.”

Whitman, Walter. "The Child and the Profligate [Concluded]." The Brooklyn Daily Eagle and Kings County Democrat 6.24 (January 29, 1847): [1]. [Brooklyn, NY]. Brooklyn Daily Eagle Online 1841-1902. ${ }^{89}$

This is the third and concluding part of this serial version of "The Child and the Profligate."

- "The Child and the Profligate." New Hampshire Sentinel 76.8 (February 19, 1874): [1]. [Keene, NH]. America's Historical Newspapers, including Early American Newspapers Series 1, 2, 3, 6 and 7, 1690-1922 and African American Newspapers, 1827-1998. (See Early American Newspapers, Series 3).

The epigraph is not included in the New Hampshire Sentinel.

ALSO REPRINTED AS:

\section{"The Child and Profligate"}

- Whitman, Walter, AUTHOR OF “THE MERCHANT'S CLERK." “THE CHILD AND PROFLIGATE.” Settler E Pennon 5.28 (October 11, 1844): [1-2]. [Smethport, M'Kean County, PA]. NewspaperARCHIVE.

In this reprint, the epigraph also precedes the story.

ADDITIONAL REPRINTS IN PART OR IN WHOLE FOR WHICH ONLY PARTIAL CITATION INFORMATION IS AVAILABLE:

- "From the Columbian Magazine. THE CHILD AND THE PROFLIGATE." Maine Cultivator and Hallowell Gazette (October 26, 1844). [Hallowell, ME]. Historical Newspaper Archives. GenealogyBank.

- "The Child and the Profligate." Salem Register (March 12, 1874). [Salem, MA]. Historical Newspaper Archives. GenealogyBank. 
NUMBER OF REPRINTS OF "The Child and the Profligate" AND "The Child and Profligate" (after its first publication in the Columbian Lady's and Gentleman's Magazine): 6

Number of Previously Unknown Reprints in Periodicals Cited Here: 5

\section{“Bervance, or Father and Son" (Item E 33, Myerson 1993, pg. 545)}

These publications of "Bervance, or Father and Son" are the only known reprints of the text in periodicals.

\section{ORIGINAL:}

Whitman, Walter. "BERVANCE: OR, FATHER AND SON." The United States Magazine, and Democratic Review 9.42 (December 1841): 560-568. [New York, NY]. American Periodicals Series Online 1740-1900. ${ }^{90}$

\section{REPRINTS IN PERIODICALS:}

- Whitman, Walter. "[From the Democratic Review for December.] BERVANCE: OR FATHER AND SON." Daily Troy Budget 48.133 (December 8, 1841, Evening): [2]. Fulton History.

The Daily Troy Budget reprints "Bervance: Or Father and Son" as a two-part serial, and this is the first installment. The last sentence of the first installment is: "A few days longer residence there, he [Luke] said, a conscious witness of is [its?] horrors, and he should be its fit inmate forever [2]." At the end of the story is the note "(Concluded in our next)" [2].

- Whitman, Walter. "[From the Democratic Review for December.] BERVANCE: OR FATHER AND SON." Daily Troy Budget 48.134 (December 10, 1841, Evening): [2]. Fulton History.

This is the second of two installments of "Bervance, Father and Son" in the Daily Troy Budget; the word "(Concluded.)" appears before the first line of the story.

- Whitman, Walter. "From the Democratic Review. BERVANCE: OR FATHER AND SON." Barre Gazette 8.34, Whole No. 398 (December 31, 1841): [1]. [Barre, Massachusetts]. America's Historical Newspapers, including Early American Nezwspapers Series 1, 2, 3, 6 and 7, 1690-1922 and African American Newspapers, 1827-1998. (See Early American Newspapers, Series 1).

- Whitman, Walter. "BERVANCE, OR, FATHER AND SON." The New Hampshire Gazette and Republican Union 94.49 (December 5, 1848): [1]. [Portsmouth, NH]. America's Historical Newspapers, including Early American Newspapers Series 1, 2, 3, 6 and 7, 1690-1922 and African American Nerwspapers, 1827-1998. (See Early American Newspapers, Series 3, included under the heading of New-Hampshire Gazette). 
- Whitman, Walter. "BERVANCE. or? [Illegible]. FATHER AND SON." Iowa County Advocate 2.50 (August 18, 1860): [1]. [Dodgeville, WI]. NewspaperARCHIVE.

NUMBER OF REPRINTS OF "Bervance, or Father and Son": 4

Number of Previously Unknown Reprints in Periodicals Cited Here: 4

“The Tomb-Blossoms” (Item E 35, Myerson, 1993, pg. 545)

\section{ORIGINAL:}

Whitman, Walter. “THE TOMB-BLOSSOMS.” The United States Magazine, and Democratic Review 10.43 (January 1842): 62-68. [New York, NY]. American Periodicals Series Online 1740-1900.

\section{REPRINTS IN PERIODICALS:}

- Whitman, Walter. "From the U. S. Magazine for Jan. THE TOMBBLOSSOMS." Pennsylvania Inquirer and National Gazette 26.14, Whole No. 3877 (January 17, 1842): [1], col F. [Philadelphia, PA]. 19 th Century U. S. Newspapers; America's Historical Nerwspapers, including Early American Nerwspapers Series 1, 2, 3, 6 and 7, 1690-1922 and African American Newspapers, 1827-1998. (See Early American Nezwspapers, Series 7, listed as the Philadelphia Inquirer).

- Whitman, Walter. "[From the United States Magazine, for January] THE TOMB BLOSSOMS." New-Bedford Register 4.4 (February 3, 1842): [4]. [New Bedford, MA]. America's Historical Newspapers, including Early American Newspapers Series 1, 2, 3, 6 and 7, 1690-1922 and African American Newspapers, 1827-1998. (See Early American Newspapers, Series 6).

- Whitman, J. [sic.]. "From the Democratic Review. THE TOMB-BLOSSOMS." The Experiment 7.28, Whole No. 340 (February 23, 1842): [1]. [Norwalk, Huron County, $\mathrm{OH}$ ]. NewspaperARCHIVE.

- Whitman, Walter. "THE TOMB-BLOSSOMS." Ladies' Garland and Family Wreath Embracing Tales, Sketches, Incidents, History, Poetry, Music, etc. 2.5 (November 1844): 106-108. [Philadelphia, PA]. American Periodicals Series Online 1740-1900.

- Whitman, Walter. "THE TOMB-BLOSSOMS." The Andover News 6.12 (November 16, 1892): [2]. [Andover, Allegany County, NY]. Andover Nerws Archive. Covering the News from 1869-1978. Andover Free Library: Newspaper Archives Online.

$<$ http://www.andoverfreelibrary.org/newspaperarchive.htm $>.{ }^{91}$

The Andover Newws (Andover, NY) reprints "The Tomb-Blossoms," on the second page, beginning in the second column, under a poem entitled "AN 
OLD SONG WITH A NEW TUNE." No author is given for the poem, but the same poem appears above the same reprinted version of Whitman's story in The New Haven News (New Haven, IN) on November 17, 1892, The Greenburgh Register (Dobbs' Ferry, NY) on November 18, 1892, in The McKean Democrat (Smethport, PA) also on November 18, 1892, in Corbett's Herald (Providence, RI) on November 19, 1892, in The Reveille (Rolfe, IA) on December 1, 1892, and in The Daily Herald (Delphos, OH) on December 28, 1897.

- Whitman, Walt. "THE TOMB-BLOSSOMS." The Nerw Haven News 1. [Issue Number Unavailable] (November 17, 1892): [4]. [New Haven, Indiana]. NerwspaperARCHIVE.

The New Haven Nerws (New Haven, Indiana) reprints "The Tomb-Blossoms" under a poem entitled "AN OLD SONG WITH A NEW TUNE." No author is given for the poem, but the same poem appears above what seems to be the same reprinted version of Whitman's story in The Andover News (Andover, NY) on November 16, 1892, in The Greenburgh Register (Dobbs' Ferry, NY) and in The McKean Democrat (Smethport, PA) on November 18, 1892, in Corbett's Herald (Providence, RI) on November 19, 1892, in The Reveille (Rolfe, IA) on December 1, 1892, and in The Daily Herald (Delphos, OH) on December 28, 1897.

- Whitman, Walt. "THE TOMB-BLOSSOMS." The McKean Democrat 14.33 (November 18, 1892): [1]. [Smethport, M'Kean County, Penna (PA)]. NewspaperARCHIVE.

The McKean Democrat (Smethport, PA) reprints "The Tomb-Blossoms" under a poem entitled "AN OLD SONG WITH A NEW TUNE." No author is given for the poem, but the same poem appears above what seems to be the same reprinted version of Whitman's story in The Andover News (Andover, NY) on November 16, 1892, in The New Haven News (New Haven, IN) on November 17, 1892, in The Greenburgh Register (Dobbs' Ferry, NY) on November 18, 1892, in Corbett's Herald (Providence, RI) on November 19, 1892, in The Reveille (Rolfe, IA) on December 1, 1892, and in The Daily Herald (Delphos, OH) on December 28, 1897.

- Whitman, Walt. "THE TOMB-BLOSSOMS." Greenburgh Register 13.20 (November 18, 1892): 2. [Dobbs' Ferry, NY]. Fulton History.

The Greenburgh Register (Dobbs' Ferry, NY) reprints "The Tomb-Blossoms" under a poem entitled "AN OLD SONG WITH A NEW TUNE." No author is given for the poem, but the same poem appears above what seems to be the same reprinted version of Whitman's story in The Andover News (Andover, NY) on November 16, 1892, in The New Haven News (New Haven, IN) on November 17, 1892, in The McKean Democrat (Smethport, PA) also on November 18, 1892, in Corbett's Herald (Providence, RI) on November 19, 1892, in The Reveille (Rolfe, IA) on December 1, 1892, and in The Daily Herald (Delphos, OH) on December 28, 1897. 
- Whitman, Walt. “THE TOMB-BLOSSOMS.” Corbett's Herald: A Paper for the Times, Fourteenth Year, No. 4. (November 19, 1892): [2]. [Providence, RI]. Google Nerws Archive Search (Full Text Available).

Corbett's Herald (Providence, RI) reprints "The Tomb-Blossoms" under a poem entitled "AN OLD SONG WITH A NEW TUNE." No author is given for the poem, but the same poem appears above what seems to be the same reprinted version of Whitman's story in The Andover News (Andover, NY) on November 16, 1892, in The New Haven News (New Haven, IN) on November 17, 1892, in The Greenburgh Register (Dobbs' Ferry, NY) on November 18, 1892, in The McKean Democrat (Smethport, PA) also on November 18, 1892, in The Reveille (Rolfe, IA) on December 1, 1892, and in The Daily Herald (Delphos, OH) on December 28, 1897.

- Whitman, Walt. "THE TOMB-BLOSSOMS." The Reveille 5.22 (December 1, 1892): [3]. [Rolfe, Pocohontas County, IA]. NewspaperARCHIVE.

The Reveille (Rolfe, IA) reprints "The Tomb-Blossoms" under a poem entitled "AN OLD SONG WITH A NEW TUNE." No author is given for the poem, but the same poem appears above what seems to be the same reprinted version of Whitman's story in The Andover News (Andover, NY) on November 16, 1892, in The New Haven News (New Haven, IN) on November 17, 1892, in The Greenburgh Register (Dobbs' Ferry, NY) on November 18, 1892, in The McKean Democrat (Smethport, PA) also on November 18, 1892, in Corbett's Herald (Providence, RI) on November 19, 1892, and in The Daily Herald (Delphos, OH) on December 28, 1897.

- Whitman, Walt. "THE TOMB-BLOSSOMS." Mexico Independent: Devoted to Local Affairs, News of the Day, and Literature 32.6 (February 8, 1893): [1]. [Mexico, NY]. Fulton History.

- Whitman, Walt. “THE TOMB-BLOSSOMS." The Daily Herald 4.168 (December 28, 1897): [3]. [Delphos, OH]. NewspaperARCHIVE.

The Daily Herald (Delphos, $\mathrm{OH}$ ) reprints "The Tomb-Blossoms" under a poem entitled "AN OLD SONG WITH A NEW TUNE." No author is given for the poem, but the same poem appears above what seems to be the same reprinted version of Whitman's story in The Andover Neww (Andover, NY) on November 16, 1892, in The New Haven News (New Haven, IN) on November 17, 1892, in The Greenburgh Register (Dobbs' Ferry, NY) on November 18, 1892, in The McKean Democrat (Smethport, PA) also on November 18, 1892, in Corbett's Herald (Providence, RI) on November 19, 1892, and in The Reveille (Rolfe, IA) on December 1, 1892.

Whitman, Walter. "THE TOMB-BLOSSOMS." The Long-Islander $103^{\text {rd }}$ Year, No. 24 (December 5, 1940): Section 1, pg. 4. [Huntington, Long Island, New York]. Suffolk Historic Nezwspapers. <http://live-brary.com/ historic-newspapers $/>.{ }^{92}$

"The TOMB-BLOSSOMS" is reprinted here immediately after the article "In Early Youth Walt Whitman Wrote 'The Tomb Blossoms"” by Walter 
S. Funnell, which focuses on the story as reprinted in James J. Brenton's book entitled, Collection of Sketches, Essays, and Poems by Practical Printers (1850).

\section{ALSO REPRINTED AS:}

\section{"The Tomb-Blossoms. Posthumous Sketch"}

- Whitman, Walter. "THE TOMB-BLOSSOMS POSTHUMOUS SKETCH." Dallas Morning News 8.23 (October 23, 1892): 13. [Dallas, TX]. Historical Newspaper Archives. GenealogyBank.com (Preview Only); America's Historical Newspapers, including Early American Newspapers Series 1, 2, 3, 6 and 7, 1690-1922 and African American Newspapers, 1827-1998 (Full-Text Available). (See Dallas Morning News Historical Archive, Early American Newspapers, Series 2).

The Dallas Morning News reprinted "The Tomb-Blossoms" nearly seven months after the death of Walt Whitman, adding "Posthumous Sketch" to the title seemingly to remind readers of the poet's passing on March 26, 1892 .

The story is accompanied by four illustrations, two of which are one-column in width, one of which is two columns in width, and one which includes the title and is also two-columns in width; there are seven columns on the page.

This illustrated version of the tale also appeared in The Galveston Daily Nerws (Galveston, TX), the Philadelphia Press (Philadelphia, PA), the Rocky Mountain Nerws (Denver, CO), and The Salt Lake Tribune (Daily, Salt Lake City, UT), on the same day, October 23, 1892. It appeared in The Salt Lake Weekly Tribune (Salt Lake City, UT) later that same week on October 27, 1892.

- Whitman, Walter. "THE TOMB-BLOSSOMS POSTHUMOUS SKETCH." The Galveston Daily News 51.213 (October 23, 1892): [10]. [Galveston, TX]. NewspaperARCHIVE.

The Galveston Daily News reprinted the illustrated version of the tale. This version also appeared in The Dallas Morning News (Dallas, TX), the Philadelphia Press (Philadelphia, PA), the Rocky Mountain News (Denver, CO), and The Salt Lake Tribune (Daily, Salt Lake City, UT) on the same day, October 23, 1892. It appeared in The Salt Lake Weekly Tribune (Salt Lake City, UT) later that same week on October 27, 1892.

The story is accompanied by four illustrations, two of which are one column in width, one of which is two columns in width, and one which includes the title and is also two columns in width; there are seven columns on the page.

“THE TOMB-BLOSSOMS." The Philadelphia Press (October 23, 1892). [with illustrations]. [Philadelphia, PA].$^{93}$ 
The Philadelphia Press reprinted the illustrated version of the tale. This version is almost certainly the same as that in The Dallas Morning News (Dallas, TX), The Galveston Daily News (Galveston, TX), the Rocky Mountain News (Denver, CO), and The Salt Lake Tribune (Daily, Salt Lake City, UT), on the same day, October 23, 1892. It appeared in The Salt Lake Weekly Tribune (Salt Lake City, UT) later that same week on October 27, 1892.

- Whitman, Walter. "The TOMB-BLOSSOMS POSTHUMOUS SKETCH.” Rocky Mountain Nerws 34 (October 23, 1892): 18, col. E. [Denver, CO]. $19^{\text {th }}$ Century U. S. Newspapers.

The Rocky Mountain News reprinted the illustrated version of the tale.

The story is accompanied by four illustrations, two of which are one column in width, one of which is two columns in width, and one which includes the title and is also two columns in width. There are seven columns of text on the page, alongside a series of advertisements that are approximately two columns in width. The paper consists of approximately nine columns.

This version also appeared in The Dallas Morning News (Dallas, TX), The Galveston Daily News (Galveston, TX), the Philadelphia Press (Philadelphia, PA), and The Salt Lake Tribune (Daily, Salt Lake City, UT) on the same day, October 23, 1892. It appeared in The Salt Lake Weekly Tribune (Salt Lake City, UT) later that same week on October 27, 1892.

- Whitman, Walter. "The TOMB-BLOSSOMS POSTHUMOUS SKETCH." The Salt Lake Tribune [The Daily Tribune] 42.186 (October 23, 1892): [14]. [Salt Lake City, UT]. Utah Digital Newspapers. J. Willard Marriott Library. The University of Utah. <http://digitalnewspapers. $\operatorname{org} />.^{94}$

The Salt Lake Tribune (Daily) reprinted the illustrated version of the tale. The story is accompanied by four illustrations, two of which are one column in width, one of which is two columns in width, and one which includes the title and is also two columns in width; there are three columns of text on the page alongside advertisements that span multiple columns. The paper seems to consist of seven columns.

This version also appeared in The Dallas Morning News (Dallas, TX), The Galveston Daily News (Galveston, TX), the Philadelphia Press (Philadelphia, PA), and the Rocky Mountain News (Denver, CO), on the same day, October 23, 1892. It appeared in The Salt Lake Weekly Tribune (Salt Lake City, UT) later that same week on October 27, 1892.

- Whitman, Walter. "The TOMB-BLOSSOMS POSTHUMOUS SKETCH." The Salt Lake Weekly Tribune Vol. [21? Illegible]. No. 36 (October 27, 1892): 8. [Salt Lake City, UT]. America's Historical Newspapers, including Early American Newspapers Series 1, 2, 3, 6 and 7, 1690-1922 and African American Newwspapers, 1827-1998. (See Early American Newspapers, Series 2, listed as the Salt Lake Tribune). ${ }^{95}$ 
The Salt Lake Weekly Tribune reprinted the illustrated version of the tale. The story is accompanied by four illustrations, two of which are one column in width, one of which is two columns in width, and one which includes the title and is also two columns in width; there are eight columns of text and illustrations on the page.

This version also appeared in The Dallas Morning News (Dallas, TX), The Galveston Daily Nerws (Galveston, TX), the Philadelphia Press (Philadelphia, PA), and the Rocky Mountain News (Denver, CO), on the same day, October 23, 1892. It appeared in The Salt Lake Tribune (Daily, Salt Lake City, UT) later that same week on October 27, 1892.

\section{ALSO REPRINTED AS:}

\section{"Her Offerings"}

- 'HER OFFERINGS. Why a Poor Woman Decorated Two Paupers' Graves. Her Dead Husband Occupied One of Them, But Which One?-An Affection That Was Finally Transferred to a Bright Reward. [COPYRIGHT, 1892]." Rochester Daily Republican SEVENTH YEAR (Evening, October 25, 1892): [2]. [Rochester, IND.]. NewwspaperARCHIVE.

The Rochester Daily Republican (Rochester, IN) reprints Whitman's “The Tomb-Blossoms" under the title of "Her Offerings." The story is accompanied by three illustrations, which are the same as those printed with the previously mentioned "The TOMB-BLOSSOMS. POSTHUMOUS SKETCH" version of the tale. The illustration that included the title for the posthumous sketches is absent here. All of the illustrations for "Her Offerings" are one-column in width, and the page consists of six columns.

This version of "Her Offerings" is then reprinted in The Wichita Daily Eagle (Wichita, Kan.) on October 28, 1892, and in the Logansport fournal (Logansport, IN) on November 17, 1892.

- 'HER OFFERINGS. Why a Poor Woman Decorated Two Paupers' Graves. Her Dead Husband Occupied One of Them, But Which One?-An Affection That Was Finally Transferred to a Bright Reward. [COPYRIGHT, 1892]." The Wichita Daily Eagle 17.140, Whole No. 2644 (Friday Morning, October 28, 1892): 3. [Wichita, Kan.]. Library of Congress. Chronicling America.

The Wichita Daily Eagle (Wichita, Kan.) reprints Whitman's “The TombBlossoms" under the title of "Her Offerings." The story is accompanied by three illustrations, which are the same as those printed with the previously mentioned "The TOMB-BLOSSOMS. POSTHUMOUS SKETCH" version of the tale. The illustration that included the title for the posthumous sketches is absent here. However, all of the illustrations for "Her Offerings" are one-column in width, and the page consists of seven columns.

This version of "Her Offerings" also appears in The Rochester Daily Republican (Rochester, IN) on October 25, 1892, and in the Logansport fournal on November 17, 1892. 
- 'HER OFFERINGS. Why a Poor Woman Decorated Two Paupers' Graves. Her Dead Husband Occupied One of Them, But Which One?-An Affection That Was Finally Transferred to a Bright Reward. [COPYRIGHT, 1892.]." Logansport fournal 17.277 (November 17, 1892): [6]. [Logansport, IN]. NewspaperARCHIVE.

The Logansport fournal (Logansport, IN) reprints Whitman's "The TombBlossoms" under the title of "Her Offerings." The story is accompanied by three illustrations, which are the same as those printed with the previously mentioned "The TOMB-BLOSSOMS. POSTHUMOUS SKETCH" version of the tale. The illustration that included the title for the posthumous sketches is absent here. All of the illustrations for "Her Offerings" are onecolumn in width, and the page consists of six columns.

This version of "Her Offerings" previously appeared in The Rochester Daily Republican (Rochester, IN) on October 25, 1892, and in The Wichita Daily Eagle (Wichita, Kan.) on October 28, 1892.

\section{INTERNATIONAL REPRINTS:}

\section{"THE TOMB-BLOSSOMS"}

- Whitman, Walter. "THE TOMB-BLOSSOMS.” The Great Western Magazine and Anglo-American fournal of Literature, Science, Art, Commercial, and Political Economy, Statistics, E c. Vol. 1 (July 1842). Ed. Isaac Clarke Pray. London: Published by Simpkin, Marshall, and Co., Stationers' Hall Court, 1842: 334-338. Google Books Search. <http://books.google.com/>.

\section{"The Tomb Flowers"}

- "The Tomb Flowers." Our Boys and Girls: a Monthly Magazine (July 1881): 51. [Ludgate Circus Buildings, 2 Castle Street City Road; London]. University of Oxford, Bodleian Libraries.

$<$ http://solo.bodleian.ox.ac.uk/primo_library/libweb/action/dlDisplay.do? vid= OXVU1 $\&$ docId $=$ oxfaleph014443046>.96

The story is modified from the original; it has been significantly condensed such that only the major plot events are included and much of Whitman's description has been removed or summed up.

Also, here the story appears in a magazine designed for children that also includes hymns and verses.

ADDITIONAL REPRINTS IN PART OR IN WHOLE FOR WHICH ONLY PARTIAL CITATION INFORMATION IS AVAILABLE:

- ["The Tomb-Blossoms."] Repository (October 23, 1892). [Canton, OH]. Historical Newspaper Archives. GenealogyBank. 
NUMBER OF REPRINTS OF "The Tomb-Blossoms" (and variant titles): 25

Number of Previously Unknown Reprints in Periodicals Cited Here: 23

\section{"The Last of the Sacred Army" (Item E 42, Myerson 1993, pg. 546)}

A reworked version of the original tale appears in Chapter 20 of Whitman's novel Franklin Evans. ${ }^{97}$

\section{ORIGINAL:}

Whitman, Walter. "The Last of the Sacred Army." The United States Magazine, and Democratic Review 10.45 (March 1842): 259-264. [New York, NY]. AmericanPeriodicals Series Online 1740-1900. ${ }^{98}$

\section{REPRINTS IN PERIODICALS:}

- Whitman, Walter. "[From the Democratic Review for March.] THE LAST OF THE SACRED ARMY.” Nerw-Bedford Register 4.11 (March 16, 1842): [4]. [New Bedford, MA]. America's Historical Newspapers, including Early American Newspapers Series 1, 2, 3, 6 and 7, 1690-1922 and African American Nerwspapers, 1827-1998. (See Early American Newspapers, Series 6).

"THE LAST OF THE SACRED ARMY." The United States Magazine, and Democratic Review 29.161 (November 1851): 463-466. [New York, NY]. AmericanPeriodicals Series Online 1740-1900.99

- Whitman, Walter. "THE LAST OF THE SACRED ARMY." Camden Democrat 40.4 (January 24, 1885): [1]. [Camden, NJ]. Google News Archive Search (Full Text Available).

On the second page of the paper is a brief article about "The Last of the Sacred Army" that reads as follows:

"On our first page will be found a patriotic tribute to the soldiers of the Sacred Army of the Revolution, written by a now venerable and highly respected citizen of this city, and published some forty years since. He will no doubt be surprised to find this production of his youthful days resurrected for the edification of the present generation, but we feel assured that it will be read now with the same interest that was felt at the time of its original publication. The American people are not ungrateful to the memory of those who risked their all for the independence of the country, and though the last of the soldiers of the Sacred Army has long since passed away, their memory is still green in the hearts of those who now enjoy the fruits of their eventful struggle" (2).

- Whitman, Walter. "The Last of the Sacred Army." Cleveland Plain Dealer. Fiftieth Year, No. 150 (May 29, 1892): 20. [Cleveland, OH]. America's Historical Newspapers, including Early American Newspapers Series 1, 2, 3, 6 
and 7, 1690-1922 and African American Newspapers, 1827-1998. (See Early American Newspapers, Series 6). (Full view unavailable).

This reprint of "The Last of the Sacred Army" is likely illustrated, and, based on its publication date, it may be like those printed in the New York Herald (New York, NY), the Rocky Mountain News (Denver, CO), and The Salt Lake Tribune (Daily, Salt Lake City, UT) on May 29, 1892, and in The Salt Lake Weekly Tribune (Salt Lake City, UT) on June 2, 1892.

- Whitman, Walter. "The Last of the Sacred Army." New York Herald, Whole No. 20369 (May 29, 1892): 12. [New York, NY]. Fulton History.

This reprint of "The Last of the Sacred Army" is illustrated, and it seems to be like those printed in the Rocky Mountain News (Denver, CO) and The Salt Lake Tribune (Daily, Salt Lake City, UT) on May 29, 1892, and in The Salt Lake Weekly Tribune (Salt Lake City, UT) on June 2, 1892.

In this paper, as well as in the Rocky Mountain News (Denver, CO), The Salt Lake Tribune (Daily, Salt Lake City, UT), and in The Salt Lake Weekly Tribune (Salt Lake City, UT), there is one illustration of the man who is "the last of the sacred army" that is two columns in width. There is also another smaller illustration of what appears to be a military medal with an image of George Washington next to the title. This page of the Herald consists of six columns.

- Whitman, Walter. "The Last of the Sacred Army." Rocky Mountain Newus 34 (May 29, 1892): 18, col. A. [Denver, CO]. $19^{\text {th }}$ Century U. S. Newspapers.

This reprint of "The Last of the Sacred Army" is illustrated, and it seems to be like those printed in the New York Herald (New York, NY), and The Salt Lake Tribune (Daily, Salt Lake City, UT) on May 29, 1892 and in The Salt Lake Weekly Tribune (Salt Lake City, UT) on June 2, 1892.

An advertisement for the upcoming features of the Sunday edition of the Rocky Mountain News appeared in the Saturday, May 28, 1892, issue of the paper. The advertisement promised that the Sunday issue would contain several "SPECIAL FEATURES," including "THE LAST OF THE SACRED ARMY. A sketch written in 1842 by the late Walt Whitman, now first published. Illustrated" (4).

In this paper, as well as in the New York Herald (New York, NY), The Salt Lake Tribune (Daily, Salt Lake City, UT), and The Salt Lake Weekly Tribune (Salt Lake City, UT) there is one illustration of the man who is "the last of the sacred army" that is two columns in width. There is also another smaller illustration of what appears to be a military medal with an image of George Washington next to the title. This page of the Rocky Mountain News consists of six columns of texts alongside large advertisements approximately two columns in width. The newspaper consists of eight columns.

- Whitman, Walter. "The Last of the Sacred Army." The Salt Lake Tribune [The Daily Tribune] 42.43 (May 29, 1892): [16]. [Salt Lake City, UT]. NerwspaperARCHIVE. 
This reprint of "The Last of the Sacred Army" is illustrated, and it seems to be like those printed in the New York Herald (New York, NY), and the Rocky Mountain News (Denver, CO) on May 29, 1892, and in The Salt Lake Weekly Tribune (Salt Lake City, UT) on June 2, 1892.

In this paper, as well as in the New York Herald (New York, NY), the Rocky Mountain News (Denver, CO), and in The Salt Lake Weekly Tribune (Salt Lake City, UT), there is one illustration of the man who is "the last of the sacred army" that is two columns in width. There is also another smaller illustration of what appears to be a military medal with an image of George Washington next to the title. This page of the Daily Tribune consists of seven columns.

The first eight pages of this newspaper have the date of Saturday, May 28, 1892, at the top of each page. Beginning with page nine and continuing through page sixteen - where Whitman's story appears-the pages are dated Sunday, May 29, 1892.

- Whitman, Walter. "The Last of the Sacred Army." The Salt Lake Weekly Tribune 21.15 (June 2, 1892): 3. [Salt Lake City, UT]. America's Historical Newspapers, including Early American Newspapers Series 1, 2, 3, 6 and 7, 1690-1922 and African American Newspapers, 1827-1998. (See Early American Newspapers, Series 2, listed as the Salt Lake Tribune).

This reprint of "The Last of the Sacred Army" is illustrated, and it seems to be like those that appeared in the New York Herald (New York, NY), the Rocky Mountain Nerws (Denver, CO), and The Salt Lake Tribune (Daily, Salt Lake City, UT) on May 29, 1892.

In this paper, as well as in the New York Herald (New York, NY), the Rocky Mountain News (Denver, CO), and in The Salt Lake Tribune (Daily, Salt Lake City, UT), there is one illustration of the man who is "the last of the sacred army" that is two columns in width. There is also another smaller illustration of what appears to be a military medal with an image of George Washington next to the title. The Weekly Tribune consists of eight columns of text.

Here, Whitman's story also appears alongside the same article on widows of Revolutionary War soldiers that was printed in The Milwaukee Sentinel (Milwaukee, WI) on May 29, 1892, just three days earlier. ${ }^{100}$ However, in the Weekly Tribune, the article's title has been changed from "Widows Many Years" to "Brides of Continentals."

- Whitman, Walt. "THE LAST OF THE SACRED ARMY." The Daily Picayune 56.133 (June 5, 1892): 19, col. F. [New Orleans, LA]. 19 ${ }^{\text {th }}$ Century U. S. Newspapers; America's Historical Nerwspapers, including Early American Nerwspapers Series 1, 2, 3, 6 and 7, 1690-1922 and African American Newspapers, 1827-1998. (See Early American Newspapers, Series 3, listed as the Times-Picayune) ${ }^{101}$ 
This reprint is followed by this note: "Written by Walt Whitman in 1842 . Published in Boston Herald."

ALSO REPRINTED AS:

\section{"Dream of Patriotism"}

- Whitman, Walter. "DREAM OF PATRIOTISM. A Hitherto Unpublished Sketch of Walter Whitman's." The Milwaukee Sentinel (The Sunday Sentinel) 14.33 (May 29, 1892): 22, col. E. [Milwaukee, WI]. $19^{\text {th }}$ Century U. S. Nerwspapers.

The Milwaukee Sentinel published Whitman's "The Last of the Sacred Army" as "Dream of Patriotism." No illustrations accompany this reprint. Whitman's story appears on the same page as an article entitled "Widows Many Years," which focuses on the nineteen surviving widows of Revolutionary War soldiers that were then drawing pensions. The widows are named, and illustrations of six of them are printed with the article. This seems particularly fitting since the narrator of Whitman's tale falls asleep during the afternoon of "one of the anniversaries of our national independence" and dreams that a crowd of men and women, including the narrator himself, are going to see the "last of the sacred army," a veteran of the Revolutionary War (22).

Below the title of the story is "MEMORY OF THE WARRIORS OF OUR GREAT FREEDOM.' All Reverence to the Last One of the Sacred Army Who Had Himself Seen the Chief. Children Were Hastening to Crown Him With Wreaths and People Were Flocking to See Him-Feelings Called Up by Fourth of July Celebrating” (22).

The story is also prefaced with the following sentence: "[This characteristic little sketch, written in 1842, has never been printed in any of Mr. Whitman's published works. In those days, the poet signed his full first name.]" (22).

\section{ALSO REPRINTED AS:}

\section{"A Dream of Patriotism"}

- Whitman, Walt. “A DREAM OF PATRIOTISM. A Hitherto Unpublished Sketch of Walt Whitman's-The Warriors of Freedom." The Weekly Sentinel and Wisconsin Farm fournal Whole No. 2870 (June 2, 1892): 2, col. E. [Milwaukee, WI]. $19^{\text {th }}$ Century U. S. Newspapers.

The Weekly Sentinel and Wisconsin Farm fournal published Whitman's "The Last of the Sacred Army" as "A Dream of Patriotism." No illustrations accompany this reprint.

Here, the story is also prefaced with the sentence: "[This characteristic little sketch, written in 1842, has never been printed in any of Mr. Whitman's published works. In those days the poet signed his full first name.]" (2). 


\section{"An Artistic Sketch"}

- “AN ARTISTIC SKETCH. A Hitherto Unpublished Story by Walter Whitman. He Called It 'The Last of the Sacred Army', and He Named It Well-The Noble Warriors of Our Freedom. [Copyright, 1892]." The Daily Fournal 17.132 (June 1, 1892): [6]. [Logansport, IN]. NerwspaperARCHIVE.

This reprint of "The Last of the Sacred Army" and the others in this section print an illustrated version of the tale that only differs slightly from that appearing in the New York Herald (New York, NY), the Rocky Mountain News (Denver, CO), and The Salt Lake Tribune (Daily) (Salt Lake City, UT) on May 29, 1892 and in The Salt Lake Weekly Tribune (Salt Lake City, UT) on June 2, 1892. Here, the illustration of the George Washington military medal is absent, and the larger illustration of the man who is "the last of the sacred army" is only one-column in width. This newspaper page consists of six columns.

- "AN ARTISTIC SKETCH. A Hitherto Unpublished Story by Walter Whitman." He Called It "The Last of the Sacred Army," and He Named It Well-The Noble Warriors of Our Freedom. [COPYRIGHT, 1892]." Rochester Daily Republican SEVENTH YEAR (Evening, June 2, 1892): [2]. [Rochester, IND.]. NewspaperARCHIVE.

The Rochester Daily Republican appears to reprint "An Artistic Sketch" and its accompanying illustration as they appeared in The Daily fournal (Logansport, IN), on June 1, 1892, and in the Rochester Weekly Republican (Rochester, IN) on June 9, 1892. Here, the illustration is one column in width, and this newspaper page consists of six columns.

- “AN ARTISTIC SKETCH. A Hitherto Unpublished Story by Walter Whitman.' He Called It 'The Last of the Sacred Army,' and He Named It Well-The Noble Warriors of Our Freedom. [COPYRIGHT, 1892]." Rochester Weekly Republican 40 (Morning, June 9, 1892): [3]. [Rochester, Fulton County, IN]. NewspaperARCHIVE.

The Rochester Weekly Republican appears to reprint "An Artistic Sketch" and its accompanying illustration as they appeared in The Daily fournal (Logansport, IN), on June 1, 1892, and in the Rochester Daily Republican (Rochester, IN) on June 2, 1892. Here, the illustration is one column in width, and this newspaper page consists of six columns.

PARTIAL REPRINT OF THE STORY AS PART OF A NEWSPAPER ARTICLE:

\section{"Decoration Day"}

- "For the Democrat. Decoration Day." Auburn Democrat 1.37 (May 27, 1869): [2]. [Auburn, NY]. Fulton History. 
This newspaper article, published on the occasion of the upcoming "Decoration Day" (Memorial Day) is largely made up of an edited version of Whitman's short story "The Last of the Sacred Army." The paper does not include the name of the author of the article.

ADDITIONAL REPRINTS IN PART OR IN WHOLE FOR WHICH ONLY PARTIAL CITATION INFORMATION IS AVAILABLE:

- ["The Last of the Sacred Army."] Boston Herald (May 29, 1892). [Boston, MA]. Historical Newspaper Archives. GenealogyBank.

- ["The Last of the Sacred Army.”]. Muskegon Chronicle (June 9, 1892). [Muskegon, MI]. Historical Newspaper Archives. GenealogyBank.

NUMBER OF REPRINTS OF "The Last of the Sacred Army" (and variant titles): 17

Number of Previously Unknown Reprints in Periodicals Cited Here: 16

\section{"The Child-Ghost: A Story of the Last Loyalist" \\ (E 148, Myerson 1993, pg. 556)}

ORIGINAL:

Whitman, Walter. "THE CHILD-GHOST; A STORY OF THE LAST LOYALIST." The United States Magazine, and Democratic Review 10.47 (May 1842): 451-459. [New York, NY]. American Periodicals Series Online $1740-1900 .{ }^{102}$

REPRINTS IN PERIODICALS:

- Whitman, Walter. "THE CHILD-GHOST; A STORY OF THE LAST LOYALIST." Daily Troy Budget 49.261 (May 10, 1842, Evening): [2]. [Troy, NY]. Fulton History.

The Daily Troy Budget reprints "The Child-Ghost; A Story of the Last Loyalist" as a two-part serial. The ending of the first installment is almost illegible. The last sentence of the first installment that it is possible to discern (at least in part) in this copy is "'Strange walls!' echoed he of the red scarf; and for the first time since his arrival, he half laughed, but it was not the laugh which comes from a man's heart" [2].

- Whitman, Walter. "THE CHILD-GHOST; A STORY OF THE LAST LOYALIST.” Daily Troy Budget 49.262 (May 11, 1842, Evening): [2]. [Troy, NY]. Fulton History.

This is the second of two installments of "The Child-Ghost; A Story of the Last Loyalist" in the Daily Troy Budget. 
- Whitman, Walter. "THE CHILD-GHOST; A STORY OF THE LAST LOYALIST." The New-York Visitor and Lady's Album (June 1842): 139143. [New York, NY]. Google Books Search. <http://books.google.com/>.

- Whitman, Walter. "From the Democratic Review for September. THE CHILD-GHOST: A Story of the Last Loyalist." Pennsylvania Inquirer and National Gazette 27.67, Whole No. 3455 (September 17, 1842): [1], col. G. [Philadelphia, PA]. 19 $9^{\text {th }}$ Century U. S. Newspapers. America's Historical Newspapers, including Early American Newspapers Series 1, 2, 3, 6 and 7, 1690-1922 and African American Nerwspapers, 1827-1998. (See Early American Newspapers, Series 7, listed as the Philadelphia Inquirer).

"The Child Ghost: A Story of the Last Loyalist." Concord (Mass.) Freeman (October 25, 1844): 1. [Concord, MA]. ${ }^{103}$

NUMBER OF REPRINTS OF "The Child-Ghost: A Story of the Last Loyalist": 4

Number of Previously Unknown Reprints in Periodicals Cited Here: 3

"A Legend of Life and Love" (E 151, Myerson, pg. 557)

\section{ORIGINAL:}

W. W. "A LEGEND OF LIFE AND LOVE." The United States Magazine, and Democratic Review 11.49 (July 1842): 83-86. [New York, NY]. American Periodicals Series Online 1740-1900. ${ }^{104}$

In the Democratic Review, the original tale begins "A very cheerless and fallacious doctrine is that which teaches to deny the yielding to natural feelings, righteously directed, because the consequences may be trouble and grief, as well as satisfaction and pleasure" (83). Whitman removes this sentence and the paragraph that follows it before publishing the story in the Brooklyn Daily Eagle on June 11, 1846.

\section{REPRINTS IN PERIODICALS:}

- W. W. "From the Democratic Review. A Legend of Life and Love." The Evening Post 40 (July 5, 1842): [2]. [New York, NY]. Fulton History.

W. W. "From the Democratic Review for July. A LEGEND OF LIFE AND LOVE." New-York Daily Tribune 2.74, Whole No. 386 (July 6, 1842): [4]. [New-York, NY]. Fulton History. ${ }^{105}$

- W. W. "A LEGEND OF LIFE AND LOVE. From the Democratic Review." Albany Evening fournal 13.3842 (July 8, 1842): [2]. [Albany, NY]. America's Historical Newspapers, including Early American Newspapers Series 1 and 2, 1690-1900 and Selected Titles from Series 3, 4, and 5, 1783-1922. (See Early American Newspapers, Series 5). 
W. W. "[From the Democratic Review] A LEGEND OF LIFE AND LOVE." The Sun No. 2706 (July 8, 1842): [1]. [New York, NY]. Fulton History. ${ }^{106}$

W. W. "From the Democratic Magazine. A LEGEND OF LIFE AND LOVE." Brother Fonathan. A Weekly Compend of Belles Lettres and the Fine Arts, Standard Literature, and General Intelligence 2.11 (July 9, 1842): 304305. [New York, NY]. American Periodicals Series Online 1740-1900. ${ }^{107}$

- W. W. "[From the Democratic Review for July.] A LEGEND OF LIFE AND LOVE." The Sun 11.42 (July 9, 1842): [1]. [Baltimore, MD]. America's Historical Newspapers, including Early American Newspapers Series 1, 2, 3, 6 and 7, 1690-1922 and African American Nerwspapers, 1827-1998. (See Early American Newspapers, Series 3).

- W. W. "From the Democratic Review. A LEGEND OF LIFE AND LOVE." Daily Troy Budget 50.6 (July 12, 1842, Evening): [2]. [Troy, NY]. Fulton History.

- W. W. "From the Democratic Review. A LEGEND OF LIFE AND LOVE." Rochester Republican 26, n.s. 1.11, Whole No. 1331 (July 12, 1842): [4]. [Rochester, NY]. Fulton History.

- W. W. "From the Democratic Review. A LEGEND OF LIFE AND LOVE." Spirit of the Times, n. s. 13.3 (July 12, 1842): [1]. [Batavia, NY]. Fulton History.

- W. W. "From the Democratic Review for July. A Legend of Life and Love." The Fredonia Censor 22.18, Whole No. 1110 (July 13, 1842): [1]. [Fredonia, Chautauque County, NY]. Fulton History.

- W. W. "A LEGEND OF LIFE AND LOVE." Hartford Daily Courant (July 13, 1842): 2. [Hartford, CT]. Google News Archive Search (Citation Only).

- W. W. "[From the Democratic Review for July.] A LEGEND OF LIFE AND LOVE." The Southern Patriot 48.7155 (July 14, 1842): [1]. [Charleston, SC]. America's Historical Newspapers, including Early American Newspapers Series 1, 2, 3, 6 and 7, 1690-1922 and African American Newspapers, 1827-1998. (See Early American Newspapers, Series 2).

- "From the Democratic Review for July. A LEGEND OF LIFE AND LOVE." New-Bedford Mercury 36.2 (July 15, 1842): [4]. [New Bedford, MA]. America's Historical Newspapers, including Early American Newspapers Series 1, 2, 3, 6 and 7, 1690-1922 and African American Nezuspapers, 18271998. (See Early American Newspapers, Series 6).

- W. W. "From the Democratic Review for July. A LEGEND OF LIFE AND LOVE." Schenectady Reflector 8.28 (July 15, 1842) [1]. [Schenectady, NY]. Fulton History.

- W. W. "A Legend of Life and Love." The Newport Mercury 81.4186 (July 16, 1842): [1-2]. [Newport, RI]. America's Historical Newspapers, including 
Early American Newspapers Series 1, 2, 3, 6 and 7, 1690-1922 and African American Newspapers, 1827-1998. (See Early American Newspapers, Series 1).

- W. W. "From the Democratic Review for July. A LEGEND OF LIFE AND LOVE.” Lowell Courier 8.1199 (July 19, 1842): [1]. [Lowell, MA]. Fulton History.

- W. W. "From the Democratic Review. A Legend of Life and Love." Auburn Fournal and Advertiser 10.11 (July 20, 1842): [1]. [Auburn, Cayuga Co., NY]. America's Historical Nerwspapers, including Early American Newspapers Series 1, 2, 3, 6 and 7, 1690-1922 and African American Newspapers, 18271998. (See Early American Newspapers, Series 6); Fulton History.

- W. W. "MISCELLANY. [From the Democratic Review for July.] A LEGEND OF LIFE AND LOVE.” New-Bedford Register 4.23 (July 20, 1842): [4]. [New Bedford, MA]. America's Historical Newspapers, including Early American Newspapers Series 1, 2, 3, 6 and 7, 1690-1922 and African American Newspapers, 1827-1998. (See Early American Newspapers, Series 6).

- W. W. "A LEGEND OF LIFE AND LOVE. From the Democratic Review." Onondaga Standard 14.29 (July 20, 1842): [1]. [Syracuse, NY]. Fulton History.

- W. W. "From the Democratic Review. A LEGEND OF LIFE AND LOVE.” Oswego Palladium 21, Whole No. 1069, n.s. 6.30 (July 20, 1842): [1]. [Oswego, NY]. Fulton History.

- W. W. "From the Democratic Review. A Legend of Life and Love." The Experiment 7.49, Whole No. 361 (July 20, 1842): [1]. [Norwalk, Huron County, OH]. NerwspaperARCHIVE.

- W. W. "MISCELLANY. From the Democratic Review. A Legend of Life and Love." New-Hampshire Patriot and State Gazette 33.1738; n.s. 8.408 (July 21, 1842): [4]. [Concord, NH]. America's Historical Newspapers, including Early American Newspapers Series 1, 2, 3, 6 and 7, 1690-1922 and African American Newspapers, 1827-1998. (Early American Newspapers, Series 1).

- W. W. "From the Democratic Review. A LEGEND OF LIFE AND LOVE." Barre Gazette 9.11, Whole No. 427 (July 22, 1842): [1]. [Barre, MA]. America's Historical Newspapers, including Early American Newspapers Series 1, 2, 3, 6 and 7, 1690-1922 and African American Newspapers, 1827-1998. (See Early American Newspapers, Series 1).

- W. W. "Miscellany. From the Democratic Review. A Legend of Life and Love." The Hagerstown Mail n.s. 10.37 (July 22, 1842): [1]. [Hagers-Town, MD]. NewspaperARCHIVE.

- W. W. "Miscellaneous Selections. From the Democratic Review. A LEGEND OF LIFE AND LOVE." Supplement to the Courant 7.15 (July 23, 1842): 113-114. [Hartford, CT]. HathiTrust Digital Library. 
$<$ http://babel.hathitrust.org/cgi/pt?id=nyp.33433081677258;view=image ; $1=\% 22$ as $\% 20$ Nathan $\% 20$ ceased $\% 22$; start $=1 ;$ size $=100 ;$ page $=$ root;seq $=$ $119 ;$ num $=113>$. ${ }^{108}$

This reprint appears on the first and second pages of this issue of the Supplement to the Courant.

- "From the Democratic Review for July A LEGEND OF LIFE AND LOVE." Universalist Union 7.36-IV. 8 vo. (July 23, 1842): 572-574. [Fulton St., New York, NY]. Google Books Search. <http://books.google.com/>.

- W. W. "[From the Democratic Review.] A LEGEND OF LIFE AND LOVE." Geneva Advertiser 1.50 (July 27, 1842): [1]. [Geneva, NY]. Fulton History.

- W. W. "From the Democratic Review for July. A LEGEND OF LIFE AND LOVE." Lancaster Examiner \& Democratic Herald 16, n.s. 4.34 [Illegible] (July 27, 1842): [1]. [Lancaster, PA]. LancasterHistory.org. The Lancaster Examiner $\mathbb{E}$ Herald. A Collection of the Access Pennsylvania Digital Repository. State Library of Pennsylvania Historic Newspapers Collection. $<$ http://www.accesspadr.org/index.php >. ${ }^{109}$

- W. W. "MISCELLANY. A LEGEND OF LIFE AND LOVE." Southport Telegraph 3.5 (July 27, 1842): [1]. [Southport, WI; office opposite the temperance house]. NewspaperARCHIVE.

- W. W. "From the Democratic Review. A LEGEND OF LIFE AND LOVE." Skaneateles Columbian 12.8, Whole No. 580 (July 28, 1842): [1]. [Skaneateles, NY]. Fulton History.

- W. W. "A LEGEND OF LIFE AND LOVE." Madison Courier n.s. 3.39, Whole No. 143 (July 30, 1842): 1. [Madison, IA.] (Indiana). NerwspaperARCHIVE. ${ }^{110}$

- "TALES OF SENTIMENT: A LEGEND OF LIFE AND LOVE. Dem. Review." The Nerw-York Mirror: a Weekly Gazette of Literature and the Fine Arts 20.31 (July 30, 1842): 245-246. [New York, NY]. American Periodicals Series Online 1740-1900.

- "MISCELLANY. From the Democratic Review. 'A LEGEND OF LIFE AND LOVE.'” Plattsburgh Republican 33.2 (July 30, 1842): [1]. [Plattsburgh, NY]. Northern New York Historical Newspapers. <http://news2. nnyln.net/>. ${ }^{111}$

- "From the Democratic Review for Fuly. A LEGEND OF LIFE AND LOVE." Massachusetts Spy 72.31, Whole No. 3619? [Illegible] (August 3, 1842): [1]. [Worcester, MA]. America's Historical Newspapers, including Early American Nezuspapers Series 1, 2, 3, 6 and 7, 1690-1922 and African American Newspapers, 1827-1998. (See Early American Newspapers, Series 6).

The Washingtonian Temperance fournal and Family Reader (August 3, 1842). [Wiscasset, ME]. ${ }^{112}$ 
- "A LEGEND OF LIFE AND LOVE. From the Democratic Review." The Democratic Expounder and Calhoun County Patriot 6.36, Whole No. 296 (August 11, 1842): [1]. [Marshall, MI]. NerwspaperARCHIVE.

- "Miscellaneous Department. From the Democratic Review. A Legend of Life and Love." The Pittsfield Sun 43.2186 (August 11, 1842): [1]. [Pittsfield, MA]. America's Historical Nezwspapers, including Early American Nerwspapers Series 1 and 2, 1690-1900 and Selected Titles from Series 3, 4, and 5, 1783-1922. (See Early American Newspapers, Series 1).

- W. W. "From the Democratic Review. A LEGEND OF LIFE AND LOVE." The North American and Daily Advertiser 71, Whole No. 20,794; Vol. 4 - No. 1055 (August 16, 1842): [1], col. G. [Philadelphia, PA]. 19 $9^{\text {th }}$ Century U. S. Newspapers; America's Historical Newspapers, including Early American Newspapers Series 1 and 2, 1690-1900 and Selected Titles from Series 3, 4, and 5, 1783-1922. (See Early American Nezwspapers, Series 4, listed as the North American).

- W. "MISCELLANEOUS. A Legend of Life and Love." The fournal 7.32, Whole No. 344 (August 17, 1842): [1]. [Huntingdon, PA]. Huntingdon County Historical Newspaper Collection. Access Pennsylvania Digital Repository. Juniata College.

- W. W. "MISCELLANY. From the Democratic Review. A LEGEND OF LIFE AND LOVE." The Western Argus n.s. 2.21, Whole No. 561 (September 14, 1842): [1]. [Lyons, Wayne Co., NY]. Fulton History.

- W. W. "From the Democratic Review, for July. A LEGEND OF LIFE AND LOVE." Literary Souvenir 5.40, Whole No. 300 (October 1, 1842): 308. [Manchester, N. H. \& Lowell \& Boston, MA]. AAS Historical Periodicals Collection: Series 3.

- “A LEGEND OF LIFE AND LOVE." Northern fournal 5.35 (October 13, 1842): [1]. [Lowville, NY]. Fulton History.

- "From the Democratic Review for Fuly. A LEGEND OF LIFE AND LOVE." Telegraph and Texas Register 7.48, Ed. 1, Whole No. 363 (November 16, 1842): [1]. [Houston, TX]. Google News Archive Search. Cruger \& Moore, editor. Telegraph and Texas Register (Houston, Tex.), Vol. 7, No. 48, Ed. 1, Wednesday, November 16, 1842, Newspaper, November 16, 1842; digital images, (http://texashistory.unt.edu/ark:/67531/metapth48208/), University of North Texas Libraries, The Portal to Texas History, http://texashistory. unt.edu; crediting Dolph Briscoe Center for American History, Austin, Texas. ${ }^{113}$

- W. W. "From the Democratic Review. A Legend of Life and Love." Daily Chronicle E Sentinel 6.274 (November 21, 1842): 1-2. [Augusta, GA]. America's Historical Newspapers, including Early American Newspapers Series 1, 2, 3, 6 and 7, 1690-1922 and African American Newspapers, 1827-1998. (See Early American Nezwspapers, Series 7, listed as the Augusta Chronicle). ${ }^{114}$ 
- W. W. "From the Democratic Review. A LEGEND OF LIFE AND LOVE." Sunbury American and Shamokin fournal 3.10, Whole No. 114 (December 3, 1842): [1]. [Sunbury, Northumberland Co., PA]. Library of Congress. Chronicling America.

- "A LEGEND OF LIFE AND LOVE." The Raleigh Register, and NorthCarolina Gazette 44.30 (April 14, 1843): [1], col. A. [Raleigh, NC]. 19 ${ }^{\text {th }}$ Century U. S. Newspapers.

- "From the Democratic Review. A LEGEND OF LIFE AND LOVE." Rutland Herald 49.30 (July 27, 1843): [1]. [Rutland, VT]. Library of Congress. Chronicling America.

- W. T. "From the Democratic Review, for Fuly 1842. A LEGEND OF LIFE AND LOVE." Southport American 3.44 (July 20, 1844): [1]. [Southport, WI]. NewspaperARCHIVE.

Whitman, Walter. "A Legend of Life and Love." The Brooklyn Daily Eagle and Kings County Democrat 5.142 (June 11, 1846): [1]. [Brooklyn, NY]. Brooklyn Daily Eagle Online. ${ }^{115}$

Whitman edited "A Legend of Life and Love," cutting the first paragraph of the original and beginning the story with, "Upon the banks of a pleasant river once stood a cottage, the residence of an ancient man whose limbs were feeble with the weight of years and of former sorrow" (1).

- Whitman, Walter. “A LEGEND OF LIFE AND LOVE.” Zion's Herald and Wesleyan fournal 17.32 (August 12, 1846): 128. [Boston, MA]. American Periodicals Series Online 1740-1900.

- Whitman, Walter. "Miscellaneous. A Legend of Life and Love." Christian Contributor And Free Missionary 3.30 (September 23, 1846): 120. [Utica, NY]. AAS Historical Periodicals Collection: Series 3.

- Whitman, Walter. "A Legend of Life and Love." Syracuse Daily fournal 2.390 (October 3, 1846): [2]. [Syracuse, NY]. Fulton History.

- “A LEGEND OF LIFE AND LOVE." The Southern Patriot 59.9446 (January 29, 1848): [2]. [Charleston, SC]. America's Historical Newspapers, including Early American Nerwspapers Series 1, 2, 3, 6 and 7, 1690-1922 and African American Newspapers, 1827-1998. (See Early American Newspapers, Series 2).

- “A Legend of Life and Love." Manufacturers' and Farmers' Fournal and Providence and Pawtucket Advertiser 27.15 (February 21, 1848): [4] . [Providence, RI]. Google News Archive Search (Full Text Available).

- "From the Democratic Review. A Legend of Life and Love." The Roman Citizen 8.41 (March 17, 1848): 1-2. [Rome, NY]. Fulton History.

- "MISCELLANY. From the Democratic Review. A Legend of Life and Love." Barre Patriot 4.39 (April 11, 1848): [1]. [Barre, MA]. America's Historical Newspapers, including Early American Newspapers Series 1, 2, 3, 6 and 
7, 1690-1922 and African American Newspapers, 1827-1998. (See Early American Nezwspapers, Series 1).

- "MISCELLANY. From the Democratic Review. A Legend of Life and Love." The Wachusett Star 1.22 (April 18, 1848): [1]. [Barre, MA]. America's Historical Newspapers, including Early American Newspapers Series 1, 2, 3, 6 and 7, 1690-1922 and African American Newspapers, 1827-1998. (See Early American Newspapers, Series 1).

"A Legend of Life and Love." Long Island Democrat (August 7, 1849). [Jamaica, NY]. ${ }^{116}$

- Whitman, Walter. "Miscellaneous. A LEGEND OF LIFE AND LOVE." The Harford Gazette, and General Advertiser 3.6 (July 5, 1850): [1]. [Bel Air, MD]. America's Historical Newspapers, including Early American Newspapers Series 1, 2, 3, 6 and 7, 1690-1922 and African American Nerwspapers, 18271998. (See Early American Newspapers, Series 7).

- Whitman, "Walter." "A LEGEND OF LIFE AND LOVE." The Brooklyn Daily Eagle (Walt Whitman Centenary Edition, with a 12-page Whitman Section) 79.150 (May 31, 1919): 10 (Walt Whitman Section). [Brooklyn, NY]. Fulton History.

ALSO REPRINTED AS:

\section{"The Legend of Life and Love"}

- W. W. "MISCELLANY. From the Democratic Review. THE LEGEND OF LIFE AND LOVE.” Mohawk Courier 9.5 (July 28, 1842): [1]. [Little Falls, NY]. Fulton History.

ALSO REPRINTED AS:

\section{"Legend of Life and Love"}

- "Legend of Life and Love." Florida Republican 4.39 (April 8, 1852): [1]. [Jacksonville, FL]. University of Florida. George A. Smathers Libraries. Florida Digital Newspapers. Florida Newspapers Subcollection: Florida Republican. <http://ufdc.ufl.edu/UF00079922/00126/search>.17

No author is identified, but the paper acknowledges the source of the story as "[Democratic Review.]" at the end of the piece.

- "An Interesting Sketch. LEGEND OF LIFE AND LOVE." The Covington fournal 6.6, Whole No. 265 (August 27, 1853): [1]. [Covington, KY]. Google News Archive Search (Full Text Available).

- W. W. "Legend of Life and Love." Lowell Daily fournal and Courier 22.5812 (June 20, 1857): [1, 4]. [Lowell, MA]. Fulton History.

- W. W. "Legend of Life and Love." St. Albans Messenger 20.35, Whole No. 1022 (July 9, 1857): 1. [St. Albans, VT]. America's Historical Newspapers, including Early American Newspapers Series 1, 2, 3, 6 and 7, 1690-1922 and 
African American Newspapers, 1827-1998. (See Early American Newspapers, Series 6).

ALSO REPRINTED AS:

\section{"A Legend of Love and Life"}

- W. W. "[From the Democratic Review for July.] A Legend of Love and Life.” Utica Observer 26.1332 (July 26, 1842): [4]. [Utica, NY]. Fulton History.

\section{ALSO REPRINTED AS:}

\section{"Life and Love"}

- "Life and Love." Berkshire County Whig 6.288 (September 10, 1846): 1. [Pittsfield, MA]. America's Historical Newwspapers, including Early American Nezwspapers Series 1, 2, 3, 6 and 7, 1690-1922 and African American Newspapers, 1827-1998. (See Early American Newspapers, Series 1).

The Berkshire County Whig seems to reprint the Brooklyn Daily Eagle version of the story under the shortened title of "Life and Love."

- "Life and Love." Newburyport Herald 51.73 (September 18, 1846): 1. [Newburyport, MA]. America's Historical Newspapers, including Early American Newspapers Series 1, 2, 3, 6 and 7, 1690-1922 and African American Newspapers, 1827-1998. (See Early American Newspapers, Series 6).

The Newburyport Herald seems to reprint the Brooklyn Daily Eagle version of the story, but, like the Berkshire County Whig, it publishes the tale with the shortened title of "Life and Love."

ADDITIONAL REPRINTS IN PART OR IN WHOLE FOR WHICH ONLY PARTIAL CITATION INFORMATION IS AVAILABLE:

- "MISCELLANY. From the Democratic Review. A LEGEND OF LIFE AND LOVE.” Republican Farmer (August 9, 1842). [Bridgeport, CT]. Historical Nerwspaper Archives. GenealogyBank.

- ["A Legend of Life and Love."]. Canton Repository (August 18, 1842). [Canton, OH]. Historical Newspaper Archives. GenealogyBank.

INTERNATIONAL REPRINTS:

\section{"A Legend of Life and Love"}

- "MISCELLANY. A LEGEND OF LIFE AND LOVE." Stanstead fournal Number 41 (August 13, 1846): [1]. [Rock Island, Stanstead, Canada]. Google News Archive Search (Full Text).

The Stanstead fournal appears to reprint the Brooklyn Daily Eagle version of the story. 
NUMBER OF REPRINTS OF "A Legend of Life and Love" (and variant titles): 71

Number of Previously Unknown Reprints in Periodicals Cited Here: 65

“The Angel of Tears" (Item E 157, Myerson, 1993, pg. 557)

ORIGINAL:

Whitman, Walter. "The Angel of Tears." The United States Magazine and Democratic Review 11.51 (September 1842): 282-283. ${ }^{118}$

REPRINTS IN PERIODICALS:

"The Angel of Tears." Brooklyn Evening Star (February 28, 1846). ${ }^{119}$

"The Angel of Tears" was reprinted in a "very slightly revised" form in The Brooklyn Evening Star. ${ }^{120}$ The edited version is Item E 232 in Myerson (Myerson, 1993, pg. 567).

INTERNATIONAL REPRINTS:

\title{
"The Angel of Tears"
}

- "THE ANGEL OF TEARS." The Lamp: A Weekly Catholic fournal of Politics, Literature, Science, the Fine Arts, E c. 7.50 (December 16, 1854): 796-797. [London, UK]. University of Oxford, Bodleian Libraries.

$<$ http://solo.bodleian.ox.ac.uk/primo_library/libweb/action/dlDisplay.do? vid $=$ OXVU1\&docId $=$ oxfaleph014088128>.121

The Lamp seems to reprint the original story from The United States Magazine and Democratic Review.

NUMBER OF REPRINTS OF “The Angel of Tears": 2

Number of Previously Unknown Reprints in Periodicals Cited Here: 1

\author{
"The Reformed" (later titled "Little Jane") ${ }^{122}$ \\ (See Franklin Evans, Item E 159, Myerson 1993, pg. 558; \\ "Lady Jane" [sic] Item E 625, Myerson 1993, pg. 605) ${ }^{123}$
}

The story most familiarly known as "Little Jane" that was a part of Franklin Evans - an embedded tale within the temperance novel — was first published as a preview of the novel. Whitman later edited and reprinted the tale separately, as a stand-alone piece in the December 7, 1846, edition of The Brooklyn Eagle and Kings County Democrat. ${ }^{124}$ 
- Whitman, Walter. “THE REFORMED.” The Sun No. 2722 (November 17, 1842): [4]. [New York, NY]. Fulton History.

This printing of "The Reformed" is the earliest known appearance in print of the story that would be embedded in Franklin Evans and later published as "Little Jane."

Here, "The Reformed" opens with a note, presumably from the editor, that praises Franklin Evans: "[We are permitted to extract the following beautiful sketch from a forthcoming novel, to be published next week at the New World office, called 'FRANKLIN EVANS, the Inebriate.' It is written by Mr. Whitman, an author whose eloquent pen is in this work devoted to a most worthy cause - the cause of Temperance.]."

- Whitman, Walter. "THE REFORMED." The Evening Post 40 (November 19, 1842): [1]. [New York, NY]. Fulton History.

This printing of "The Reformed" is the second of the four earliest known appearances in print of the story that would be embedded in Franklin Evans and later published as "Little Jane."

"The Reformed" opens with a note, presumably from the editor: "The following extract, which will be read with interest is taken from a novel in the press, by Mr. Whitman, entitled 'FRANKLIN EVANS, the Inebriate.' It will be published next week, at the office of the New World."

- Whitman, Walter. “THE REFORMED.” Daily Troy Budget 47.124 (November 26, 1842, Afternoon): [2]. [Troy, NY]. Fulton History.

This reprint of "The Reformed" appeared in the Daily Troy Budget only a few days after the publication of Franklin Evans, and it is the third of only four known printings of the story under this title.

This reprint is preceded by a note that is largely the same-save slight variations to account for the later publication date- from that printed in the New York Sun: "[We extract the following beautiful sketch from a novel published at the New World office, called 'FRANKLIN EVANS, the Inebriate.' It is written by Mr. Whitman, an author whose eloquent pen is in this work devoted to the most worthy cause-the cause of Temperance.]" [2].

PRINTINGS OF THE STORY AS "The Reformed" FOR WHICH ONLY PARTIAL PUBLICATION INFORMATION IS AVAILABLE:

- Whitman, Walter. "Miscellany. The Reformed." Republican Farmer (November 29, 1842). [Bridgeport, Connecticut]. GenealogyBank.

This reprint of "The Reformed" appeared in the Republican Farmer nearly a week after the publication of Franklin Evans; it is the fourth of only four known printings of the story that was embedded in the novel under this 
title. This is also the only known reprint of this version of the tale outside of New York.

\section{ALSO REPRINTED AS:}

\section{"From 'Franklin Evans"'}

- Whitman, Walter. "FROM 'FRANKLIN EVANS."” Wiskonsan Enquirer 5.7 (February 9, 1843): [1]. [Madison, WI]. NewspaperARCHIVE.

Here, the editors of the Wiskonsan Enquirer have extracted and printed the embedded story from Franklin Evans that will later be edited and published as "Little Jane." Unlike the version of the story titled "The Reformed," which begins by explaining that it is Mr. Marchion who relates this tale to Franklin Evans, this extraction begins with the words, "Lift up!' was ejaculated as a signal [. . .]," like the version Whitman titled "Little Jane."

FIRST PRINTING AS A SEPARATE TALE (EDITED) TITLED "Little fane":

Whitman, Walter. "LITTLE JANE." The Brooklyn Daily Eagle and Kings County Democrat 5.293 (December 7, 1846): [1]. [Brooklyn, NY]. Brooklyn Daily Eagle Online, 1841-1902. ${ }^{125}$

The Brooklyn Daily Eagle reprinted "Little Jane," "with few changes" from the Franklin Evans version of the tale. ${ }^{126}$

\section{REPRINTS IN PERIODICALS:}

- Whitman, Walter. "YOUTH'S DEPARTMENT. Little Jane." Universalist Union 12. No. 6.-IX (December 19, 1846): 95-96. [Fulton St., New York, NY]. Google Books Search. <http://books.google.com/>.

The Universalist Union presents "Little Jane" as a story for young readers. The editorial note that precedes this reprint also emphasizes the tale's moral: "The following touching little sketch is from the pen of Walter Whitman, the present accomplished editor of the Brooklyn Eagle, though it had met the public eye before, through other channels. But such articles never grow old. They speak to the heart at all times and seasons. And we never suffer injury by familiarity with them. Let our little folks read it attentively and draw a lesson of kindness therefrom."127

- "MISCELLANY. Little Jane.” Rhinebeck Gazette and Dutchess Family Visitor 1.44 (March 2, 1847): 1. [Rhineback, NY]. (Dutchess Co.). Fulton History.

NUMBER OF REPRINTS OR PREVIEWS OF THE NOVEL AS "The Reformed," "From 'Franklin Evans" $A N D$ THEN $A S$ "Little Jane": 7

Number of Previously Unknown Printings or Reprints in Periodicals Cited Here: 7 
Note: These figures reflect the number of times the "Little Jane" story, including versions of the story printed under different titles, appeared as a separate tale. They do not account for reprints of or new editions of the novel as a whole.

\title{
"Lingave's Temptation" ("Lingrave's Temptation," Item E 2U (Myerson 2011, pg. 86), "Renumbering of old entry for 'Lingrave's Temptation'” E 3024 (Myerson 1993, pg. 847) ${ }^{128}$
}

\author{
ORIGINAL: UNKNOWN.
}

KNOWN PRINTINGS IN PERIODICALS:

Whitman, Walter. "Miscellaneous. For the New-York Observer. LINGAVE'S TEMPTATION." New York Observer and Chronicle 20.48. Whole No. 1020 (November 26, 1842): 192. [New York, NY]. American Periodicals Series Online 1740-1900.

Although the original printing of "Lingave's Temptation" is unknown, this printing of the short story includes "For the New-York Observer" in the heading (rather than indicating the story is for or from another publication). Here, the publication date of "Lingave's Temptation" also nearly coincides with that of Whitman's novel Franklin Evans and that of "The Reformed."

It is important to note, as Thomas Brasher does, that "[a] unique clipping of the tale, apparently taken from the periodical in which it originally appeared, is in the Feinberg Collection, with Whitman's revisions for Collect.”"129

There are no other known printings of "Lingave's Temptation" in periodicals.

NUMBER OF REPRINTS OF "Lingave's Temptation":

Reprints in Periodicals: UNKNOWN.

\section{"The Unrelenting" (later titled "The Death of Wind-Foot") (See Franklin Evans, Item E 159, Myerson, 1993, pg. 558) ${ }^{130}$}

The story most familiarly known as "The Death of Wind-Foot" was originally a part of Franklin Evans - an embedded tale within the temperance novel. Whitman later reprinted the tale separately, and it was believed to have been first published as a stand-alone piece in edited form in the June 1845 edition of The American Review. ${ }^{131}$

REPRINTING OF THE STORY AS: "The Unrelenting” (FROM The New World AND Franklin Evans): 
- "From the New World. THE UNRELENTING. From "FRANKLIN EVANS" or "FRANKLIN ENANS" [sic]? [Illegible]. Wiskonsan Enquirer 5.6 (February 1 OR 2, 1843): [1]. NewspaperARCHIVE. ${ }^{132}$

This Wiskonsan Enquirer reprint of the embedded story of the death of young Wind-Foot is the earliest known reprint of the tale to date. It is also the only known reprinting of the Franklin Evans version of the tale with only slight variations and/or editorial omissions from the original story, which was embedded within the novel. The newspaper's editor may have chosen the story because of its focus on Native American characters since it appears on the first page in the first column, directly under a poem entitled, "THE NORTH AMERICAN INDIAN'S DEATH SONG": Translated from the German of Schiller, by the late $A W$. P [illegible] ss. The title of "THE UNRELENTING" comes from the name of the one of the principal characters, the father of Wind-Foot, who witnesses the child being killed by a member of the Kansi tribe as revenge for Unrelenting's murder of the Kansi warrior's own father.

FIRST PRINTING AS A SEPARATE TALE (EDITED) TITLED "The Death of Wind-Foot":

"THE DEATH OF WIND-FOOT." The American Review: A Whig fournal of Politics, Literature, Art, and Science 1.6 (June 1845): 639-642. [New York, NY]. American Periodicals Series Online 1740-1900. ${ }^{133}$

This is the first printing of the story under the title of "The Death of WindFoot"; it has "a number of verbal variants" from the version that can be found within the novel Franklin Evans. ${ }^{134}$

\section{REPRINTS IN PERIODICALS:}

- Whitman, Walter, "FOR THE AM. REVIEW. 'THE DEATH OF WINDFOOT." The Rover: A Weekly Magazine of Tales, Poetry, and Engravings, Also Sketches of Travel, History, and Bibliography 5.14 (June 21, 1845): 215218. [New York, NY]. American Periodicals Series Online 1740-1900.

- Whitman, W. "The Death of Wind Foot. From the American Review." Albany Evening fournal 16.4642 (July 16, 1845): [2]. [Albany, NY]. America's Historical Newspapers, including Early American Newspapers Series 1 and 2, 1690-1900 and Selected Titles from Series 3, 4, and 5, 1783-1922. (See Early American Newspapers, Series 5).

- Whitman, W. "MISCELLANY. From the American Review. THE DEATH OF WIND FOOT.” The Rome Sentinel 7.39, n.s. 1.18 (July 29, 1845): [1]. [Rome, NY]. Fulton History.

- Whitman, W. “The Death of Wind Foot." Daily Saratoga Republican 2.51 (Evening, August 7, 1845): [2]. [Saratoga Springs, NY]. Fulton History.

"The Death of Wind Foot" is printed in the Daily Saratoga Republican as a work of serial fiction. This is the first of two installments. 
- Whitman, W. "The Death of Wind Foot." Daily Saratoga Republican 2.52 (Evening August 8, 1845): [2]. [Saratoga Springs, NY]. Fulton History.

This is the concluding installment of "The Death of Wind Foot."

Whitman. W. "From the American Review. The Death of Wind Foot." The Brooklyn Eagle and Kings County Democrat 4.208 (August 29, 1845): [2]. [Brooklyn, NY]. Brooklyn Daily Eagle Online 1841-1902. ${ }^{135}$

"The Death of Wind Foot" is reprinted in The Brooklyn Eagle and Kings County Democrat as a work of serial fiction. This is the first of two installments.

Whitman, W. "From the American Review. The Death of Wind Foot. (Concluded.)." The Brooklyn Eagle and Kings County Democrat 4.209 (August 30, 1845): [1-2]. [Brooklyn, NY]. Brooklyn Daily Eagle Online 1841-1902.

$<$ http://eagle.brooklynpubliclibrary.org/Default/Skins/BEagle/Client. asp? Skin=Beagle $>.{ }^{136}$

This is the concluding installment of "The Death of Wind Foot."

- Whitman, W. "[From the American Review] The Death of Windfoot." Cayuga Patriot 32.39, Whole No. 1625 (December 3, 1845): [1]. [Auburn, NY]. Fulton History.

- “THE DEATH OF WIND-FOOT." The Geneva Gazette 26.2, n.s. No. 1306 (January 14, 1870): [1]. [Geneva, Ontario County, N.Y.]. Fulton History.

- “THE DEATH OF WIND-FOOT." The Saratogian 18.6 (January 27, 1870): [1]. [Saratoga Springs, NY]. Fulton History.

ALSO REPRINTED AS:

\section{"The Death of Wind-Foot. An Indian Story."}

- Whitman. W. "THE DEATH OF WIND-FOOT. An Indian Story." The Age 14.29 (August 1, 1845): [1]. [Augusta, ME]. America's Historical Newspapers, including Early American Newspapers Series 1 and 2, 1690-1900 and Selected Titles from Series 3, 4, and 5, 1783-1922. (See Early American Newspapers, Series 5).

Whitman, W. "LADIES DEPARTMENT. The Death of Wind-Foot. AN INDIAN STORY." Massachusetts Ploughman and New England Fournal of Agriculture 4.45 (August 9, 1845): [4]. [Boston, MA]. American Periodicals Series. ${ }^{137}$

- Whitman, W. "Select Tales. From the American Review. THE DEATH OF WIND-FOOT. An Indian Story." The Newport Mercury 84.4347 (August 16, 1845): [1-2]. [Newport, RI]. America's Historical Newspapers, including Early American Newspapers Series 1, 2, 3, 6 and 7, 1690-1922 and African 
American Newspapers, 1827-1998. (See Early American Newspapers, Series 2).

- Whiteman, W. [sic.] "From the American Review. THE DEATH OF WIND-FOOT. AN INDIAN STORY." Cumberland Alleganian 7.20 (September 27, 1845): [1]. [Cumberland, MD]. NewspaperARCHIVE.

Whitman, W. "The Story Teller. From the American Review? [Illegible]. THE DEATH OF WIND-FOOT. AN INDIAN STORY." Maine Farmer. A Family Paper; Devoted to Agriculture, Mechanic Arts, General Intelligence, \&c. 13.40 (October 2, 1845): [4]. [Augusta, ME]. American Periodicals Series. ${ }^{138}$

Whitman, W. "THE DEATH OF WIND-FOOT. AN INDIAN STORY." Crystal Fount and Rechabite Recorder: Organ of the Independent Order of Rechabites, and devoted to the Cause of Temperance in General 5.6 (October 18, 1845): 81-84. [Fulton St., New York, NY]. Google Books Search. <http:// books.google.com/>. ${ }^{139}$

The Crystal Fount and Rechabite Recorder reprinted "The Death of WindFoot: An Indian Story" without change from American Review text. ${ }^{140}$

- Whitman, W. "Select Story. THE DEATH OF WIND-FOOT. AN INDIAN STORY." The Weekly Kansas Chief 17.45, Whole No. 877 (April 30, 1874): [1]. [Troy, KS]. Library of Congress. Chronicling America.

ALSO REPRINTED AS:

\section{"Death of Wind-Foot"}

- Whitman, W. "DEATH OF WIND-FOOT.” Northern fournal 8.25 (July 31, 1845): [1]. [Lowville, NY]. Fulton History.

- Whitman, W. "MISCELLANY. From the American Review. DEATH OF WIND FOOT." Independent American and General Advertiser 1.33 (August 22, 1845): [1]. [Platteville, WT, (WI)]. NewspaperARCHIVE.

ADDITIONAL REPRINTS IN PART OR IN WHOLE FOR WHICH ONLY PARTIAL CITATION INFORMATION IS AVAILABLE:

- "An Indian Story From the American Review The Death of Wind Foot." Philadelphia Inquirer [Pennsylvania Inquirer]. (July 7, 1845). [Philadelphia, PA]. Historical Newspaper Archives. GenealogyBank.

- Whitman, W. "The death of Wind-foot: an Indian death." The Dollar Newspaper 3.6 (July 16, 1845). [Philadelphia, PA?]. Special Whitman Collection. Rollins Library Catalogue. Rollins College (Winter Park, FL). (Citation Only). 
$<$ http://sirsi.rollins.edu/uhtbin/cgisirsi/?ps=zRSqpn $8 \mathrm{Hgf} /$ SIRSI/117850162/5/0>.

- Whitman, W. "SELECT TALE. From the American Review. THE DEATH OF WIND FOOT." Poughkeepsie fournal (August 9, 1845). [Poughkeepsie, NY]. Historical Newspaper Archives. GenealogyBank.

\section{INTERNATIONAL REPRINTS:}

\section{"The Death of Wind-Foot"}

- Whitman, W. "THE DEATH OF WIND-FOOT." Colonial Times and Tasmanian 34.1819 (April 7, 1846): [4]. [Hobart, Van Diemen's Land]. (Van Diemen's Land became known as Tasmania in 1856). Trove Digitised Nerwspapers and More. National Library of Australia. <http://trove.nla.gov. $\mathrm{au} />$. ${ }^{141}$

According to its masthead, the paper is the "Colonial Times with which is incorporated The Tasmanian." At the top of subsequent pages, the title is simply listed as the Colonial Times and Tasmanian. It was published twice per week and sold for six pence.

On the second page of the April 7, 1846 issue is a notice that reads as follows:

"COLONIAL TIMES AND TASMANIAN: The two original fournals of Van Diemen's Land CONSOLIDATED. OPEN TO ALL-INFLUENCED BY NONE."

"This Journal is published on the Evening of every Tuesday and Friday, and circulates extensively throughout the Australian Colonies, India, China, Europe, and America. It is regularly filed at the office of Messrs. Simmonds and Ward, General Agents, Cornhill, London, and at the Jerusalem Coffee House" (2).

NUMBER OF REPRINTS OF "The Unrelenting" (and variant titles): 22

Number of Previously Unknown Reprints in Periodicals Cited Here: 18

Note: These figures reflect the number of times "The Death of Wind-Foot" appeared as a separate tale, including versions of the story printed under different titles, not its publication as a tale embedded within Franklin Evans.

\footnotetext{
"The Love of the Four Students: A Chronicle of New-York" (Later Titled "The Boy-Lover") ("The Boy-Lover," Item E 177, Myerson 1993, pgs. 560-561) ${ }^{142}$
} 


\section{ORIGINAL:}

- “THE LOVE OF THE FOUR STUDENTS: A CHRONICLE OF NEWYORK." The New Mirror 2.10 (December 9, 1843): 153-155. [Ann-Street, Near Broadway, New York, NY]. Google Books Search. <http://books. google.com/>.

The New Mirror, edited by George Pope (G. P.) Morris and Nathaniel Parker (N. P.) Willis does not include the name of the author with this printing of the tale, but the plot events and the names of the characters clearly identify the story as one that will become the basis for Whitman's "The Boy-Lover." In other words, this story is either an earlier version of "The Boy-Lover" written by Whitman himself or it is a story written by someone else that Whitman borrowed from extensively before making some revisions in order to create "The Boy-Lover."

This version of the tale begins with the narrator's thoughts about love: " $\mathrm{O}$ SUBTLE spirit, Love! In our earlier years, when the heart is fresh and the impulses strong, how potent your influence over us for good or for evil!" "143

In the American Review version of the story, the tale is now titled "The Boy-Lover," and it begins: "Listen, and the old will speak a chronicle for the ears of the young! It is a brave thing to call up the memory of fires long burnt out - at least we withered folk believe so-and delight so to act."144

\section{REPRINTS IN PERIODICALS:}

- "From the New Mirror. THE LOVE OF THE FOUR STUDENTS. A CHRONICLE OF NEW-YORK." The Hudson River Chronicle 7.10 (December 19, 1843): [1]. [Sing-Sing, Westchester County, NY]. America's Historical Newspapers, including Early American Newspapers Series 1, 2, 3, 6 and 7, 1690-1922 and African American Newspapers, 1827-1998. (See Early American Newspapers, Series 1).

- "From the New Mirror. THE LOVE OF THE FOUR STUDENTS. A CHRONICLE OF NEW-YORK.” Boon's Lick Times 4.46 (January 27, 1844): [1]. [Fayette, Missouri]. Library of Congress. Chronicling America.

REPRINTED IN EDITED FORM AS:

\section{"The Boy-Lover"}

"THE BOY-LOVER." The American Review: A Whig Fournal of Politics, Literature, Art and Science I.V (May 1, 1845): 479-482. [New York, NY]. American Periodicals Series Online 1740-1900. ${ }^{145}$

REPRINTS IN PERIODICALS AS “THE BOY-LOVER": 
- "MISCELLANY. From the American Review for May. THE BOY-LOVER." New-Hampshire Statesman and State fournal 24.1253 (May 30, 1845): [1], col. A. [Concord, NH]. 19 $9^{\text {th }}$ Century U. S. Newspapers.

- "From the American Review. The Boy-Lover." Alton Telegraph \& Democratic Review 10.23 (June 7, 1845): [1]. [Alton, IL]. NewspaperARCHIVE.

- “THE BOY LOVER. AMERICAN REVIEW.” Ladies' Garland and Family Wreath Embracing Tales, Sketches, Incidents, History, Poetry, Music, etc. 6.2 (February 1846): 44-46. [Philadelphia, PA]. American Periodicals Series Online 1740-1900.

Whitman, W. "The Boy-Lover." The Brooklyn Daily Eagle and Kings County Democrat 7.2 (January 4, 1848): [1]. [Brooklyn, NY]. Brooklyn Daily Eagle Online 1841-1902.146

This is the first installment of "The Boy-Lover," which is concluded in the January 5, 1848, edition.

Whitman, W. "The Boy-Lover. (Concluded from yesterday.)." The Brooklyn Eagle and Kings County Democrat 7.3 (January 5, 1848): [1]. [Brooklyn, NY]. Brooklyn Daily Eagle Online 1841-1902. ${ }^{147}$

This is the second and final installment of "The Boy-Lover."

NUMBER OF REPRINTS OF "The Love of the Four Students. A Chronicle of New York" $A N D$ "The Boy-Lover": 7

Number of Previously Unknown Printings (including original) and Reprints in Periodicals Cited Here for the First Time: 6

\section{“Eris: A Spirit Record" (Item E163, Myerson 1993, pg. 558)}

\section{ORIGINAL:}

Whitman, Walter. "ERIS; A SPIRIT RECORD." The Columbian Lady's and Gentleman's Magazine 1.3 (March 1844): 138-139. [New Yok, NY]. ${ }^{148}$

\section{REPRINTS IN PERIODICALS:}

- Whitman, Walter. "ERIS: A SPIRIT RECORD." The Monthly Hesperian, and Odd-Fellows' Literary Magazine 1.2 (May 1850): 63-64. [Detroit, MI?]. AAS Historical Periodicals Collection: Series 3.

ALSO REPRINTED AS:

“The Love of Eris-A Spirit Record" (E 455, Myerson, 1993, pg. 588) ${ }^{149}$ 
Whitman, Walter. "The Love of Eris. - A Spirit Record." The Brooklyn Daily Eagle and Kings County Democrat 5.199 (August 18, 1846): [1]. Brooklyn Daily Eagle Online, 1841-1902.

NUMBER OF REPRINTS OF "Eris: A Spirit Record" AND "The Love of Eris-A Spirit Record": 2

Number of Previously Unknown Reprints in Periodicals Cited Here: 1

“The Little Sleighers" (Item E 172, Myerson 1993, pg. 560)

ORIGINAL:

Whitman, Walter. "THE LITTLE SLEIGHERS. A SKETCH OF A WINTER MORNING ON THE BATTERY." The Columbian Lady's and Gentleman's Magazine, Embracing Literature in Every Department: Embellished with the Finest Steel and Mezzotint Engravings, Music, and Colored Fashions 2 (September 1844): 113-114. [New York, NY]. American Periodicals Series Online 1740-1900. ${ }^{150}$

REPRINTS IN PERIODICALS:

- Whitman, Walter. "THE LITTLE SLEIGHERS. A Sketch of a Winter Morning on the Battery." Pennsylvania Inquirer and National Gazette 31.58, Whole No. 3488 (September 6, 1844): [1]. [Philadelphia, PA]. America's Historical Newspapers, including Early American Newspapers Series 1, 2, 3, 6 and 7, 1690-1922 and African American Newspapers, 1827-1998. (See Early American Nerwspapers, Series 7, listed as the Philadelphia Inquirer).

NUMBER OF REPRINTS OF "The Little Sleighers": 1

Number of Previously Unknown Reprints in Periodicals Cited Here: 1

\section{"Shirval: A Tale of Jerusalem" (E 174, Myerson 1993, pg. 560)}

In The Early Poems and the Fiction, Thomas Brasher records the March 1845 edition of the Aristidean as the magazine in which Whitman's "Shirval: A Tale of Jerusalem" first appeared. More recently, however, Jerome Loving has written that Whitman "had published in the [Brooklyn Evening] Star as early as February 18, 1845-printing 'Shirval: A Tale of Jerusalem' possibly before it appeared in the March issue of the Aristidean." 151

ORIGINAL:

"Shirval: A Tale of Jerusalem." Brooklyn Evening Star (February 18, 1845). ${ }^{152}$ 
"Art. IV.-SHIRVAL: A TALE OF JERUSALEM." Aristidean: A Magazine of Reviezws, Politics, and Light Literature 1.1 (March 1845): 12-15. [New York, NY]. AmericanPeriodicals Series Online 1740-1900. ${ }^{153}$

\section{REPRINTS IN PERIODICALS:}

- "MISCELlANEOUS. From the Aristidean. SHIRVAL! A TALE OF JERUSALEM.” Gettysburg Republican Compiler 27.29, Whole No. 1379 (April 7, 1845): [1]. [Gettysburg, PA]. NewwspaperARCHIVE.

- "SHIRVAL. A TALE OF JERUSALEM." Massachusetts Ploughman and New England Fournal of Agriculture 5.8 (November 22, 1845): 4. [Boston, MA]. American Periodicals Series Online 1740-1900.

"Shirval-A Tale of Jerusalem." The Brooklyn Eagle and Kings County Democrat 5.22 (January 22, 1846): [2]. [Brooklyn, NY]. Brooklyn Daily Eagle Online, 1841-1902. ${ }^{154}$

"Shirval: A Tale of Jerusalem." New York Sunday Times (October 10, 1847). [New York, NY]. ${ }^{155}$

- "Shirval. A TALE OF JERUSALEM." The Mountain Democrat 26.4 (January 25, 1879): [2]. [Placerville, El Dorado County, CA]. NewspaperARCHIVE.

The tale has "-Selected" printed after it, but no author is listed.

This version of "Shirval. A TALE OF JERUSALEM" is different from both the printings in The Aristidean and in the Brooklyn Daily Eagle insofar as the first three paragraphs of those versions are omitted.

Here, the tale begins with "Very beauteous was the coming of the sun, one day, over the cities of Judah." In the other versions, this sentence marks the start of the fourth paragraph of the piece. The reference to "-Selected" at the conclusion of the story, then, may be meant to indicate that the editor has published a "selected" part of the story and omitted the beginning paragraphs of earlier versions. The changes could also reflect Whitman's revisions to the story.

- "Shirval. A TALE OF JERUSALEM." Ukiah City Press 2.33 [Ukiah City, Mendocino County, CA]. February 14, 1879 [6]. NewspaperARCHIVE.

The tale has "--Selected" printed after it, but no author is listed.

This version of "Shirval. A TALE OF JERUSALEM" appears to be the same as that printed in The Mountain Democrat (Placerville, CA) on January 25, 1879.

["Shirval: A Tale of Jerusalem"]. Revised from manuscript in William White. Daily Collegian 53.87 (Wayne State University) (February 28, 1963): $8 .{ }^{156}$

NUMBER OF REPRINTS OF "Shirval: A Tale of Jerusalem": 8 
Number of Previously Unknown Reprints in Periodicals Cited Here: 4

\section{"Revenge and Requital; A TALE OF A MURDERER ESCAPED" (Item E 179, Myerson 1993, pg. 561)}

\section{ORIGINAL:}

Whitman, Walter. "REVENGE AND REQUITAL; A TALE OF A MURDERER ESCAPED. I II. III. IV.” The United States Magazine, and Democratic Review 17.85 (July/Aug 1845): 105-111. [New York, NY]. American Periodicals Series Online 1740-1900. ${ }^{157}$

REPRINTS IN PERIODICALS AS "Revenge and Requital: A Tale of a Murderer Escaped" AND "Revenge and Requital":

"Revenge and Requital: A Tale of a Murderer Escaped." New York Weekly Nerws (August 16, 1845): 2. ${ }^{158}$

The New York Weekly News reprints the Democratic Review text, with its original title "Revenge and Requital: A Tale of a Murderer Escaped.".159

- Whitman, Walter. "Miscellany. REVENGE AND REQUITAL." Barre Patriot 2.6 (August 29, 1845): [1-2]. [Barre, MA]. America's Historical Newspapers, including Early American Newspapers Series 1, 2, 3, 6 and 7, 1690-1922 and African American Nerwspapers, 1827-1998. (See Early American Newspapers, Series 1).

NUMBER OF REPRINTS OF "Revenge and Requital: A Tale of a Murderer Escaped": 2

Number of Previously Unknown Reprints in Periodicals Cited Here: 1

“Some Fact-Romances" (Item E 205, Myerson 1993, pg. 564)

ORIGINAL:

"ART. XV-SOME FACT-ROMANCES ORIGINAL." Aristidean: $A$ Magazine of Reviews, Politics, and Light Literature 1.6 (December 1845): 444-449. [New York, NY]. American Periodicals Series Online 1740-1900. ${ }^{160}$

The original publication of "Some Fact-Romances" included all of the "Fact Romances" listed below. Whitman chose to reprint the pieces separately. There are no known reprints of "Some Fact Romances" as a complete work in periodicals. 
REPRINTS IN PERIODICALS:

"Fact-Romance" I:

"A Fact Romance of Long Island." The Brooklyn Daily Eagle and Kings County Democrat 5.301 (December 16, 1846): [2]. [Brooklyn, NY]. Brooklyn Daily Eagle Online, 1841-1902. ${ }^{161}$

"Fact-Romance" II:

“The Old Black Widow." The Brooklyn Daily Eagle and Kings County Democrat 5.273 (November 12, 1846): [2]. [Brooklyn, NY]. Brooklyn Daily Eagle Online, 1841-1902. ${ }^{162}$

"Fact-Romance" IV:

Mabbott, Thomas Ollive. "Walt Whitman and The Aristidean." American Mercury, II (June 1924): 206-207. ${ }^{163}$

"Fact-Romance" V:

"An Incident on Long Island Forty Years Ago." The Brooklyn Daily Eagle and Kings County Democrat 5.308 (December 24, 1846): [2]. [Brooklyn, NY]. Brooklyn Daily Eagle Online, 1841-1902. ${ }^{164}$

- "AN INCIDENT ON LONG ISLAND FORTY YEARS AGO." The Anglo American, a fournal of Literature, Nerws, Politics, the Drama, Fine Arts, Etc. 8.15 (January 30, 1847): 351. [New York, NY]. American Periodicals Series Online 1740-1900.

- "AN INCIDENT ON LONG ISLAND FORTY YEARS AGO." Spirit of the Times; A Chronicle of the Turf, Agriculture, Field Sports, Literature and the Stage 16.49 (Jan 30, 1847): 584. [New York, NY]. American Periodicals Series Online 1740-1900.

- "An Incident on Long Island Forty Years Ago." The Long Island Farmer and Queens County Advertiser 14.44 (February 9, 1847): [1]. [Jamaica, NY]. Fulton History.

NUMBER OF REPRINTS OF ANY PART OF THE ORIGINAL WORK:

Reprints in Periodicals: 7

NUMBER OF REPRINTS OF "Fact-Romance" V AS "An Incident on Long Island Forty Years Ago": 4

Number of Previously Unknown Reprints of "AN INCIDENT ON LONG ISLAND FORTY YEARS AGO” in Periodicals Cited Here: 3 


\section{A STORY PREVIOUSLY ATTRIBUTED TO WALT WHITMAN: \\ "The Little Minstrel Girl-A Tale of Truth" \\ (Item E 903A, Myerson 2011, 77)}

In Walt Whitman: The Song of Himself, Jerome Loving suggests that Whitman could be the author of "The Little Minstrel Girl-A Tale of Truth," a short story that appeared in the Brooklyn Daily Eagle on July 13, 1847, while Whitman served as the editor of the paper. ${ }^{165}$ It is true that the theme of temperance and the characterization of Alice as a beautiful young minstrel girl in a tavern have much in common with the plots and the characters of several other pieces of Whitman's short fiction-most importantly, "Dumb Kate: An Early Death" and "The Boy-Lover." Even the subtitle "A Tale of Truth" sounds like that of Franklin Evans, which includes the phrase "a Tale of the Times." However, the publication history of "The Little Minstrel Girl-A Tale of Truth," reveals that the piece is unlikely to be Whitman's work.

\section{ORIGINAL:}

- "ORIGINAL. FOR THE ARIEL. THE TOWN TATLER-NO. 18." The Ariel. A Semimonthly Literary and Miscellaneous Gazette 5.16 (November 26, 1831): [246-247]. [Philadelphia, PA]. American Periodicals Series Online 1740-1900.

Since this tale first appeared in 1831, it is unlikely that Whitman is the author of the original version for two primary reasons: first, the story was originally published before Whitman's thirteenth birthday, and second, because it was first published in Philadelphia. If the story were Whitman's, it is more likely that it would have been printed first in New York like the rest of his fiction. At the same time, the Brooklyn Daily Eagle version of this tale appears to be a reprint of that published a month earlier in a Gettysburg, Pennsylvania paper; therefore, it seems that Whitman did not rewrite or revise the original tale, but rather reprinted it in full from an earlier source.

\section{ALSO REPRINTED AS:}

- “LADIES' DEPARTMENT. A TALE OF INTEREST. THE TOWN TATLER." Southern Pioneer and Evangelical Liberalist 5.45 (June 11, 1836): 370. [Baltimore, MD]. Google Books Search.

Under the heading of "A TALE OF INTEREST," the editor writes, "We have more than once perused the following simple and affecting story. It originally appeared in the Ariel, formerly published in Philadelphia. Accidentally meeting with it, we have concluded to give it a place in our columns, trusting that it may awaken in the breasts of our readers, especially the younger portion of them, those filial emotions which best adore, and most powerfully lead to ennoble and purify the human heart. -ED." 
ALSO REPRINTED AS:

\section{"Alice the Minstrel"}

- "THE MIRROR. From the Ariel. ALICE, THE MINSTREL." The Star and Adams County Republican Banner 2.42, Whole No. 94 (January 24, 1832): [1]. [Gettysburg, PA]. Google News Archive Search.

- "From the Ariel. Alice-The Minstrel." Maryland Gazette 87.10 (March 8, 1832): [4]. [Annapolis, MD]. 19 $9^{\text {th }}$ Century U. S. Historical Newspapers.

- "MISCELlANY. ALICE, THE MINSTREL. From the Ariel." Republican Advocate 1.23 n.s., Whole No. ? [Illegible] (June 19, 1832): [1]. [Batavia, NY]. Fulton History.

- "MiscellaneOUS. AliCE, THE MINSTREL. From the Ariel." Farmers' Advocate 10.47 (November 21, 1832): [1]. [Bath, Steuben Co., NY]. Fulton History.

ALSO REPRINTED AS:

\section{"The Little Minstrel"}

- “THE LITTLE MINSTREL." The Monthly Traveler or, Spirit of the Periodical Press 7.11 (November 1836): 403-404. [Boston, MA]. Google Books Search.

ALSO REPRINTED AS:

\section{"Alice-the Philadelphia Minstrel"}

- “ALICE-the Philadelphia Minstrel." Columbian Register 25.1282 (June 17, 1837): [4]. [New Haven, CT]. America's Historical Newspapers, including Early American Newspapers Series 1 and 2, 1690-1900 and Selected Titles from Series 3, 4, and 5, 1783-1922. (See Early American Newspapers, Series $5)$.

- "ALICE-THE PHILADELPHIA MINSTREL." Auburn fournal and Advertiser 5.21 (October 4, 1837): [1]. [Auburn, Cayuga County, NY]: [1]. Fulton History.

- "ALICE-THE PHILADELPHIA MINSTREL." Supplement to the Connecticut Courant 4.67 (November 4, 1837): 532-533. Google Books Search.

ALSO REPRINTED AS:

\section{"Romance of Reality. A Tale of Truth."}

- "ROMANCE OF REALITY. A TALE OF TRUTH." The Indiana Palladium IV.41 (January 30, 1847): [1]. [Vevay, IN]. NewspaperARCHIVE. 
ALSO REPRINTED AS:

\section{"Romance in Reality"}

- "MISCELlaneOUS. ROMANCE IN REALITY." South Carolina Temperance Advocate and Register of Agriculture and General Literature 8.32 (February 11, 1847): [1]. [Columbia, SC]. 19 ${ }^{\text {th }}$ Century U. S. Newspapers.

ALSO REPRINTED AS:

\section{“The Little Minstrel Girl-A Tale of Truth" (Item E 903A, Myerson 2011, 77)}

- "Miscellaneous. THE LITTLE MINSTREL GIRL, A Tale of Truth." Republican Compiler 29 ${ }^{\text {th }}$ Year, No. 38 (June 14, 1847): [1]. [Gettysburg, PA]. NewspaperARCHIVE.

"The little minstrel girl—a tale of truth." The Brooklyn Daily Eagle and King's County Democrat 6.164 (July 13, 1847): [1]. [Brooklyn, NY]. Brooklyn Daily Eagle Online, 1841-1902.

There are variations between the story printed in the Brooklyn Daily Eagle and the original version from the Ariel. However, the Brooklyn Daily Eagle version of the story appears to be a reprinting of that from the June 14, 1847, edition of the Republican Compiler.

- “THE LITTLE MINSTREL GIRL: A Tale of Truth.” The Huntress 11.32, Whole No. 1442 (July 17, 1847): [1]. [Washington City, D. C.]. American Periodicals Series.

ALSO REPRINTED AS:

"Sarah, the Minstrel"

- D. D. Ellis? [Illegible]. "MISCELLANEOUS. FOR THE JOURNAL. Sarah the Minstrel." Herkimer County fournal 17.39, Whole No. 912 (August 23, 1855): [1]. [Little Falls, NY]. Fulton History.

The character of "Alice" is renamed "Sarah" in this version of the story-in which the opening sentences and some of the phrasing have been altered from the original - and the author appears to be given as "D. D. Ellis."

NUMBER OF REPRINTS OF "The Little Minstrel Girl—A Tale of Truth" (and variant titles): 15

Number of Previously Unknown Reprints in Periodicals Cited Here: 14

Technische Universität Dortmund

Stephanie M. Blalock 


\section{NOTES}

1 Walt Whitman, Complete Poetry and Collected Prose, ed. Justin Kaplan (New York: Library of America, 1996), 951. Hereafter, PP.

2 Ibid., 951.

3 Horace Traubel, With Walt Whitman in Camden, 9 vols. (Vol. 1, Boston: Small Maynard, 1906; Vol. 2, New York: D. Appleton, 1908; Vol. 3, New York: Mitchell Kinnerley, 1914; Vols. 4-7, Carbondale, Illinois: Southern Illinois UP, 1959, 1964, 1986, and 1992, respectively; Vols. 8-9, Oregon House, CA: W.L. Bentley, 1996), 1:93. Hereafter, $W W W C$. Available on the Walt Whitman Archive (whitmanarchive.org).

4 Thomas L. Brasher, ed., The Early Poems and the Fiction (New York: New York University Press, 1963), 125n1. Hereafter, EPF.

5 Traubel, $W W W C, 1: 93$.

6 Ed Folsom and Kenneth Price, "Biography: Walt Whitman," The Walt Whitman Archive, (whitmanarchive.org). Hereafter, "Biography: Walt Whitman."

7 Henry Seidel Canby, Walt Whitman, an American: A Study in Biography (New York: Houghton Mifflin Company, 1943), 41. Hereafter, $A S B$.

8 Canby, $A S B$, 39; Brasher, $E P F$, xviii.

9 Walt Whitman, Walt Whitman: The Correspondence, ed. Edwin Haviland Miller, 6 vols. (New York: New York University Press, 1961-1977), 1:26. Hereafter, Corr. In 1982, Herbert Bergman argued in support of the poet's insistence on the popularity of his fiction, writing, "Whitman was not exaggerating: the year of its initial appearance, 'Death in the School-Room' was twice reprinted, and two other 1841 Whitman stories were also reprinted. . . . Of seven 1842 stories, five were reprinted" (5). See, Herbert Bergman, "A Hitherto Unknown Whitman Story and a Possible Early Poem." Walt Whitman Review 28 (March 1982): 3-15. Hereafter, "Hitherto Unknown."

10 Brasher, ed., EPF, Appendix A, 335-339. For earlier publication histories, including bibliographical citations for the original publication as well as previously discovered reprints of Whitman's stories, see William White, "Walt Whitman's Short Stories: Some Comments and a Bibliography," Papers of the Bibliographical Society of America 52 (1958), 300-306. For addenda to these bibliographies, see G. Thomas Tanselle, "Whitman's Short Stories: Another Reprint," Papers of the Bibliographical Society of America 56 (1962), 115; William White, "Addenda to Whitman's Short Stories," Papers on the Bibliographical Society of America 57 (1963), 221-222; William White, "Two Citations: An Early Whitman Article and an Early Reprinting of 'Death in the School-Room," Walt Whitman Quarterly Review 5 (Summer 1987), 36-37; William White, "Whitman as Short Story Writer: Two Unpublished Manuscripts," Notes and Queries, Vol. CVII, n. s. IX (March 2, 1962), 87-89.

11 David S. Reynolds, Walt Whitman's America: A Cultural Biography (New York: Vintage, 1996), 75. Hereafter, WWA.

12 Bergman, "Hitherto Unknown," 4.

13 Ibid., 3.

14 "The Madman" appeared in the New York Washingtonian and Organ on January 28, 1843; for "The "Fireman's Dream: With the Story of His Strange Companion, A Tale of Fantasie," see, Bergman, "Hitherto Unknown," 7-14. 
15 Ibid., 4.

16 Ibid., 14.

17 In the case of "The Madman" or "The Fireman's Dream," one would be looking for an additional printing of the original chapters and/or a continuation of the pieces within other periodicals.

18 Most of these reprints of Whitman's fiction were discovered by searching periodical databases accessible at the University of Iowa Libraries, the library at the Technische Universität Dortmund (TU Dortmund) in Dortmund, Germany, and the Iowa City Public Library, as well as websites and digital newspaper archives that are freely available online. I am also thankful for the advice and assistance in searching provided by my colleagues and friends at both universities. I have included notes to indicate when access to particular materials was provided by a university library and/ or when access requires a subscription or the payment of any fees. The titles of individual stories were used as search terms along with variants of those titles whenever such variants were observed in print. For example, "Death in the School-Room" was reprinted as "Death in a School-Room" and "A Thrilling Sketch from Life," (among others) and "The Last of the Sacred Army" was reprinted at least once as "Dream of Patriotism" and as "A Dream of Patriotism" (See especially pgs. 191-194 and pgs. 216-217, respectively).

19 Christopher Castiglia and Glenn Hendler, eds. "Introduction" to Franklin Evans, or The Inebriate: A Tale of the Times, By Walter Whitman(Durham, NC: Duke University Press, 2007), xiii. Hereafter, Franklin Evans.

20 Walter Whitman, “THE REFORMED," The Sun No. 2722 (November 17, 1842),4, Fulton History: Old New York State Historical Newspapers, (fultonhistory. com). Old Fulton New York Post Cards or Fulton History: Old New York State Historical Newspapers, is a searchable repository of more than 23 million newspaper pages, primarily from New York. The site's creator Tom Tryniski digitizes newspaper pages from print and microfilm copies and pays the expenses of the site himself with the help of donations from users. Hereafter, Fulton History.

21 Walter Whitman, “THE REFORMED," The Evening Post 40 (November 19, 1842), 1, Fulton History.

22 Whitman, Franklin Evans, 30.

23 Reynolds, $W W A, 75$.

24 Whitman, Corr., 1:26.

25 Folsom and Price, "Biography: Walt Whitman."

26 M. W. H., "Some New Books: Walt Whitman," The Sun (March 10, 1907), Section 3,pg. 2.

27 W.W., "DEATH IN THE SCHOOL-ROOM. A FACT," The United States Magazine, and Democratic Review 9.38 (August 1841), 181, American Periodicals Series Online, 1740-1900. American Periodicals Series Online, by ProQuest, offers access to digitized images of the pages of journals and magazines published in the United States from 1740 until the turn of the $20^{\text {th }}$ Century. Users can browse or search the collection.

28 Bergman, "Hitherto Unknown," 5. 
29 Park Benjamin, editor of The New World, issued a separately printed "extra" edition of the newspaper that included literary works: "Franklin Evans first appeared as such an extra, where it occupied thirty-one double-columned pages" (xxvi). Castiglia and Hendler also give November 24, 1842, as the date Franklin Evans appeared (xxxviii). See Castiglia and Hendler, "Introduction" to Whitman, Franklin Evans, ix-lvii.

30 Joseph Jay Rubin, The Historic Whitman (University Park: Pennsylvania State University Press, 1973), 363n2. Hereafter, THW.

31 W. W., "A LEGEND OF LIFE AND LOVE," The United States Magazine, and Democratic Review 11.49 (July 1842), 84. American Periodicals Series Online, 1740-1900. Hereafter, "A Legend."

32 Ibid., 84.

33 Ibid., 85.

34 Rubin, $T H W, 86$. The New York Sun also printed Whitman's story “The Reformed" on November 17, 1842.

35 The dates given in parentheses refer to the short story's original publication.

36 See Castiglia and Hendler, "Introduction" in Whitman, Franklin Evans, xxxix. As early as December 17, 1842, The New York Sun explicitly informed readers that "Death in the School-Room" was written by "Whitman." The paper published a piece entitled, "Our City Schools," which discusses the Sun's coverage of educational matters of interest to readers, and in the final paragraph, the writer quotes from the story, explaining, “'Happily,' says Whitman, in his sketch of Death in the school room, 'Happily, a worthier and more philosophical system is proving to men that children can be better governed than by lashes and tears and sighs. We are waxing towards that consummation when one of the old-fashioned school-masters, with his cow-hide, his heavy birch rod, and his many ingenious methods of child torture, will be gazed upon as a scorned memento of an ignorant, cruel, and exploded doctrine!'” In fact, Whitman gets the last word here because the article ends with this quote. See "Our City Schools," The Sun (December 16, 1842), 2, Fulton History.

37 Joel Myerson, Walt Whitman: A Descriptive Bibliography (Pittsburgh and London: University of Pittsburgh Press, 1993) Figure A1.1: Binding C, 5. Hereafter, $A$ Descriptive Bibliography.

38 For information on the various printings of Franklin Evans, see William G. Lulloff, "Franklin Evans; or The Inebriate," in J. R. LeMaster and Donald Kummings, ed., Walt Whitman: An Encyclopedia (New York: Garland Publishing, 1998); The Walt Whitman Archive, Ed Folsom and Ken Price, ed., <http://whitmanarchive. org/criticism/current/encyclopedia/entry_81.html>; "Franklin Evans," Brasher, EPF, Appendix A, 336.

39 Jean Downey, "Introduction" in Walt Whitman, Franklin Evans (Edited for the Modern Reader by Jean Downey), (Lanham, MD: The Rowman \& Littlefield Publishers, Inc., 1967), 15.

40 Brasher, EPF, viii; Folsom and Price "Biography: Walt Whitman."

41 The Daily Troy Budget's reprint of "The Reformed," appears to be the same version as that printed in The Sun; however, the note preceding the story has been altered to reflect the Budget's later, November 26, 1842, publication date. 

History.

43 See Meredith McGill, American Literature and the Culture of Reprinting, 1834-1853 (Philadelphia: University of Pennsylvania Press, 2003).

44 See Susan Belasco, "Introduction to Whitman's Poems in Periodicals," The Walt Whitman Archive, <http:/www.whitmanarchive.org/published/periodical/general_introduction/index.html>; "Bibliography of Whitman's poems first published in periodicals," The Walt Whitman Archive, <http://www.whitmanarchive.org/published/ periodical/bibliography/index.html>.

\section{Myerson, A Descriptive Bibliography.}

46 The version of "Death in the School-Room. A Fact" collected in the Early Poems and Fiction is that which is printed in Whitman's Specimen Days and Collect. The story is edited slightly, including the deletion of the sentence "The widow was now childless," which was part of the original ending. See Brasher, EPF, 55n1, 60n3.

47 America's Historical Newspapers, specifically, the Early American Newspapers Series by Readex, a Division of NewsBank, allows users to search digitized issues of United States newspapers from as early as 1690 , and its coverage extends into the $20^{\text {th }}$ Century. Although currently Early American Newspapers has Series 1-9 available, many universities select a few specific series for library users. The Early American Newspapers Series numbers provided in the bibliography's citations are taken from the Readex (a Division of NewsBank) Series "Title Lists," which is available here: <http://www. readex.com/readex/index.cfm?content $=362>$. However, depending on a university's selection or type of subscription, all titles included within a particular "Series" on this Readex site may not be accessible at every institution.

48 America's Historical Newspapers includes column headings such as "MISCELLANY" as part of the "Headline" in the lists of search results it provides. It also includes attributions such as "From the Democratic Review" that appear above or alongside Whitman's stories. I have also decided to include the column headings and attributions as part of my own citations; I have placed this information in quotation marks along with the title of each story. In an effort to maintain consistency among my bibliography entries, I have tried to view digitized images of periodical pages to obtain the information even when column headings and attributions were not typically included in the search results or citation information from other databases.

49 William White, "Two Citations: An Early Whitman Article and an Early Reprinting of 'Death in the School-Room," Walt Whitman Quarterly Review 5 (Summer 1987), 36-37. Hereafter, "Two Citations."

50 Early American Newspapers records the title of the paper as Madisonian for the Country but also indicates that the paper was published as The Madisonian.

51 Brasher, EPF, Appendix A, 335.

52 Some parts of this copy are illegible, including parts of the masthead and a small portion of the story itself. The volume and issue number are not legible on this issue, but the following issue in the series does contain this information; thus, the publication information for this citation was deduced from that of the next issue. However, much of the story itself is legible, and it is undoubtedly Whitman's work.

53 Google News Archive Search allows users to search newspaper pages that have been digitized and are freely available. Searches also return materials that require users to 
pay a fee for the content. For further information on the newspapers that have been scanned, see <http://news.google.com/newspapers $>$.

54 The $19^{\text {th }}$ Century U.S. Newspapers is a Gale Group Database that provides digitized images of individual articles and full pages of newspapers from across the U.S. For further information on this database and other Gale databases, see < http://www.gale. cengage.com/>. Hereafter, $19^{\text {th }}$ Century U.S. Newspapers.

55 All references to NewspaperARCHIVE or NewspaperARCHIVE.com are to the Access NewspaperARCHIVE Institutional Version, which is accessible at the Iowa City Public Library. NewspaperARCHIVE.com is an online newspaper database that provides access to digitized images of newspaper pages from 1607 to the present and adds new pages on a daily basis. It is owned and operated by Heritage Archives, Ltd. In order to view detailed citation information for search results, the full text of articles, and/ or to use some of the site's research tools, it is necessary to become a paid member of the site and/or to have institutional access. Hereafter, NewspaperARCHIVE.

56 White, "Two Citations"; G. R. Thompson, "An Early Unrecorded Printing of Walt Whitman's 'Death in the School-Room," "Papers of the Bibliographical Society of America 67 (1973), 64, Periodical Archives Online, Online, Chadwyck PAO Collection 5 Extension 1, ProQuest Information and Learning Company, University of Iowa Libraries.

57 The American Antiquarian Society (AAS) Historical Periodicals Collection by EBSCOhost is available in five series and provides access to digitized images of the AAS's extensive collection of American periodicals published between 1691 and 1877. Hereafter, AAS Historical Periodicals Collection.

58 The Library of Congress' Chronicling America: Historic American Newspapers, produced by the National Digital Newspaper Program (NDNP) provides free access to a searchable selection of newspaper pages published during the period of 1836-1922. For a more detailed description of the site, see <http://chroniclingamerica.loc.gov/ about/>. Hereafter, Chronicling America.

59 Brasher, EPF, Appendix A, 335; White, "Two Citations."

60 This digital collection allows users to search digitized pages from the Huntingdon Gazette (1806-1839), as well as the later Huntingdon fournal (1830s through the mid-19 ${ }^{\text {th }}$ Century).

61 Early American Newspapers records the title as the Gloucester Telegraph, but also indicates that the paper was published as The Telegraph.

62 Early American Newspapers records the title as the Macon Weekly Telegraph, but also indicates that the paper was published as The Macon Georgia Telegraph.

63 William White, "Whitman as Short Story Writer: Two Unpublished Manuscripts," Notes and Queries, CVII, n.s. IX, 87-89; White, "Two Citations"; Brasher, EPF, Appendix A, 339.

64 This newspaper is damaged, and a small part of the story is missing.

65 The Sturgis Library's Barnstable Digital Newspaper Archive provides free access to digitized pages of The Barnstable Patriot from 1830 to 1930. Users can browse or search the collection.

66 Pennsylvania State University Libraries' Pennsylvania Civil War Newspaper Collection provides free access to a selection of Pennsylvania newspapers published between 
February 23, 1831, and February 14, 1877. Users can browse or search the collection. Hereafter, Pennsylvania Civil War Newspapers.

67 Brasher, EPF, Appendix A, 335. The Brooklyn Daily Eagle Online, 1841-1902, produced by the Brooklyn Public Library, provides free access to digitized pages of the Brooklyn Daily Eagle newspaper published between October 26, 1841, and December 31,1902 . Users can browse or search the newspapers.

68 Early American Newspapers records the title of the paper as New-Hampshire Gazette but also indicates that the paper was published as The New Hampshire Gazette and Republican Union.

69 Bertram Holland Flanders, Early Georgia Magazines: Literary Periodicals to 1865 (Athens: University of Georgia Press, 2010), 101.

70 The ProQuest Historical Newspapers: Chicago Tribune database provides digitized images of articles and pages from the Chicago Tribune between the years of 1847 and 1989.

71 The DePauw University Libraries' Digitizing Greencastle: Newspapers 1837-1974, provides free access to digitized pages of local newspapers during this 137-year period. Users can browse or search the collection.

72 Early American Newspapers records the title as the Weekly Wisconsin Patriot, but also indicates that the paper was published as the Wisconsin Patriot.

73 Drawing on newspaper collections from the University of North Carolina at Greensboro (UNCG) and the Greensboro Historical Museum, The Greensboro Historical Newspapers Collection provides free access to digitized images of local newspapers published from 1826-1946. Users can search or browse the collection. For further information on the collection's coverage and to search, see $<$ http://libcdm1.uncg.edu/ $\mathrm{cdm} /$ landingpage/collection/GSOPatriot>.

74 GenealogyBank is an online genealogy resource from NewsBank, Inc. that provides access to digitized images of historical newspapers along with military records and government documents among other materials. In order to access genealogical records, detailed citation information, and/or the full-text of historical newspaper articles from GenealogyBank's "Newspaper Archives 1690-2010, All 50 States," it is necessary to purchase a subscription. Hereafter, GenealogyBank.

75 Part of the Georgia Newspaper Project, the Columbus Enquirer Archive provides access to images of the Enquirer published from 1828 to 1890 . Users can browse or search the archive, but are required to download a free Plug-In in order to view the newspaper images.

76 Brasher, EPF, 61n1.

77 Early American Newspapers records the title as the North American, but also indicates that the paper was published as the North American and Daily Advertiser.

78 Brasher, EPF, Appendix A, 335.

79 The Inventory of the Trent Collection of Whitmania online does not specify a city of publication for The Northern Pioneer. However, the Library of Congress' Chronicling America: Historic American Newspapers lists The Northern Pioneer as a weekly newspaper edited by Edwin Plummer and Edward H. Elwell and published in Portland, Cumberland, Maine. The first edition of the paper (Vol. 1, No. 1) was 
printed on July 1, 1848, and the final number (Vol. 1, No. 17) on October 21, 1848. Based on these dates, one can conclude that the Vol. 1, No. 15 of The Northern Pioneer would have been published on October 7,1848 , and, therefore, it is likely that this is the paper in which "Wild Frank's Return" appeared. See <http://chroniclingamerica. loc.gov/lccn/sn84022119/>.

80 Early American Newspapers records the title as the Weekly Eagle, but also indicates that the paper was published as The Semi-Weekly Eagle.

81 Brasher, EPF, Appendix A, 335.

82 Because of the significant differences between "A Child's Champion" and "The Child and the Profligate," I have not counted the latter as a reprint of the former. I have also attempted to distinguish between the two here since the only known reprints of the story are not of the original, but of "The Child and the Profligate," and it is possible that further research will lead to the discovery of reprints of the original version of the tale.

83 Brasher, EPF, 68n1-2.

84 Ibid., Appendix A, 335.

85 Early American Newspapers records the title as the Philadelphia Inquirer, but also indicates that the paper was published as the Pennsylvania Inquirer.

86 Brasher, EPF, Appendix A, 335.

87 Brasher, EPF, Appendix A, 365.

88 Ibid., Appendix A, 335.

89 Ibid., Appendix A, 335.

90 Ibid., 80n1.

91 The Andover News Archive provides free access to digitized pages of Andover newspapers from the late 1860 s to the late 1970 s. Users can browse the collection.

92 The Public Libraries of Suffolk County's New York's Suffolk Historic Newspapers project provides free access to a searchable collection of digitized images of the pages of 12 local newspapers.

93 William White, "Walt Whitman's Short Stories: Some Comments and a Bibliography," Papers of the Bibliographical Society of America 52 (1958), 306; Brasher, EPF, Appendix A, 335.

94 The University of Utah's Utah Digital Newspapers Collection offers free access to digitized pages of a selection of the state's newspapers. Users can browse or search the collection.

95 Early American Newspapers records the title as the Salt Lake Tribune, but the paper was published as The Salt Lake Weekly Tribune.

96 Oxford's Bodleian Libraries provide free access to digitized copies of some British periodicals, including Our Boys and Girls, a Monthly Magazine. Issues of Our Boys and Girls from 1877-1885 are available to view and download.

97 Myerson, A Descriptive Bibliography, 546.

98 Brasher, EPF, 95n1. 
100 For a description of the article, please see the bibliography entry under "Dream of Patriotism."

101 Early American Nerwspapers records the title as the Times-Picayune, but the paper was published as The Daily Picayune.

102 Brasher, EPF, 101n1.

103 William White, "Addenda to Whitman's Short Stories." In "Bibliographical Notes," Papers of the Bibliographical Society of America 57 (1963), 222.

104 Brasher, EPF, 115n1.

105 Rubin, THW, 363; Brasher, EPF, Appendix A, 336.

106 Rubin, $T H W, 363$.

107 Brasher, EPF, Appendix A, 336; Rubin, $T H W, 363$.

108 This reprint of Whitman's "A Legend of Life and Love" appears in an issue of the Supplement to the Connecticut Courant in 1842, and is bound in a larger, digitized volume available from the HathiTrust Digital Library. The full title of the publication is: Supplements to the Connecticut Courant, for the Year 1842: Containing Tales, Travels, History, Biography, Poetry, and a Great Variety of Miscellaneous Articles, Vols. 7-8, published by John L. Boswell. HathiTrust Digital Library is a repository for digital preservation and provides access to digitized books and serials. If you are not a member of one of the site's partner institutions some materials will not be accessible; however, parts of the collection will still be available for online viewing.

109 The Lancaster Examiner \& Herald Digital Collection, part of the Lancaster County Digitization Project, provides free access to images of the pages of the newspaper from 1834-1872. Users can browse or search the collection.

110 NerwspaperARCHIVE lists this title as Madison Daily Democrat; I use the title as printed on the first page of this issue of the paper in my citation.

111 The Northern New York Library Network's Northern New York Historical Newspapers collection provides free access to digitized images of pages from more than sixty-five newspapers in seven Northern New York counties. Users can search all the titles published in a single county at once or choose a particular newspaper to search.

112 Rubin, $T H W, 89$.

113 Digital images of the pages of the Telegraph and Texas Register are part of The Texas Digital Newspaper Program. This collection provides free access to newspapers from the state of Texas beginning in 1829 and extending until the present.

114 Early American Newspapers records the title as the Augusta Chronicle but also indicates that the paper is published as the Daily Chronicle and Sentinel.

115 Brasher, EPF, Appendix A, 336.

116 Jerome Loving, Walt Whitman: The Song of Himself (Berkeley: University of California Press, 2000), 142, hereafter, Song of Himself; Rubin, THW, 363.

117 Digitized images of the Florida Republican are part of the University of Florida's Florida Digital Nerwspaper Library. The collection provides access to historical and current Florida newspapers. The newspaper images are freely available and searchable. 
118 Brasher, EPF, Appendix A, 336.

119 See also, Ibid., 120n1.

120 Ibid., Appendix A, 336.

121 According to the title page for Volume Seven, The Lamp is edited by T. E. Bradley and is "devoted to the religious, moral, physical, and domestic improvement of the working classes."

122 I have not counted the first printing of the story as "Little Jane" as a reprint of "The Reformed." I am attempting to distinguish between "The Reformed" as an excerpt from and a tale embedded within Franklin Evans and the separate printing of the tale as "Little Jane" since each version of the story has its own set of reprints.

123 In Walt Whitman: A Descriptive Bibliography (1993), Myerson designates the story as "Lady Jane" when the title should be "Little Jane."

124 Brasher, EPF, Appendix A, pg. 337.

125 Ibid., Appendix A, pg. 337.

126 Ibid., Appendix A, pg. 337.

127 Universalist Union 12. No. 6.-IX (December 19, 1846), 96.

128 Joel Myerson, Supplement to "Walt Whitman: A Descriptive Bibliography" (University of Iowa Press, Iowa City, IA), 2011. The story appears in the New York Observer and Chronicle with the title "Lingave's Temptation"; Brasher's volume also prints it as "Lingave's Temptation" (See EPF, 331-334).

129 Brasher, EPF, Appendix A, 331n1; 338-339.

130 Here, I have attempted to distinguish between the embedded version of the story from Franklin Evans and the printing of the story as "The Death of Wind-Foot," since it is possible that further research could lead to the discovery of additional reprints of each version of the story.

131 Brasher, EPF, Appendix A, pg. 336-337.

132 NewspaperARCHIVE dates this paper February 1, 1843; however, on the second page of the issue, the date appears to read, "Thursday, February 2, 1843." February 1,1843 , was a Wednesday, and the paper was a weekly, with the previous edition listed as having been published on January 26,1843 , and the following edition having been published on February 9, 1843. According to the Library of Congress' Chronicling America: Historic American Newspapers, the paper was published by H. Reed in Madison, Wisconsin, in 1842 and 1843 and edited by D. Lambert from Sept. 22, 1842-June 8, 1843. This issue of the paper clearly indicates "David Lambert" as the editor and is certainly Volume V, which confirms 1843 as the year of publication. See <http:// chroniclingamerica.loc.gov/lccn/sn85033137/>.

133 Brasher, EPF, Appendix A, 336-337.

134 Ibid., Appendix A, 337.

135 Ibid., Appendix A, 336-337.

136 Ibid., Appendix A, 336-337. 
137 William White, "Whitman's Short Stories: More Addenda," Papers of the Bibliographical Society of America 69 (1975), 402.

138 Ibid., 403.

139 Brasher, EPF, Appendix A, 336-337.

140 Ibid., Appendix A, 337.

141 The National Library of Australia provides access to digitized Australian newspapers from each state and territory published from 1803-1954, as well as digital images of diaries, letters, and journal articles through Trove. Trove is a free online service that allows the full-text searching of newspapers and also returns relevant results from the site's other resources and collections about Australia.

142 I have not counted the first printing of the story as "The Boy-Lover" as a reprint of "The Love of the Four Students." I am attempting to distinguish between the two versions of the story since each has its own set of reprints.

143 "The Love of the Four Students," New Mirror, 153.

144 The American Review: a Whig Fournal of Politics, Literature, Art and Science 1.5 (May 1, 1845), 479.

145 Brasher, EPF, 302n1.

146 William White, "Walt Whitman's Short Stories: Some Comments and a Bibliography," Papers of the Bibliographical Society of America 52 (1958), 303.

147 Ibid., 303.

148 Brasher, EPF, Appendix A, 337.

149 According to Brasher, "there are a few unimportant differences in punctuation and capitalization between the original 'Eris: A Spirit Record' and the Brooklyn Daily Eagle version of the tale, titled 'The Love of Eris: A Spirit Record'" (EPF, 280n1).

150 Ibid., $254 \mathrm{n} 1$.

151 Loving, Song of Himself, 91.

152 Ibid., 91. In order to count the number of reprints here, I have allowed that one of these two possibilities is the original and the other is a reprint.

153 Brasher, EPF, 292n1.

154 Rubin, $T H W, 368$.

155 Scott Giantvalley mentions this reprint in his bibliography of "Writings About Whitman," noting that Mordecai Noah composed a headnote to the reprinting that called the story a "touching and ingenious sketch." See Giantvalley, Walt Whitman, 1838-1939: a reference guide (Boston: G. K. Hall \& Co, 1981), 3, 1847.5.

156 See Myerson, A Descriptive Bibliography, 560.

157 Brasher, EPF, 309n1.

158 William White, “Addenda to Whitman's Short Stories," Papers of the Bibliographical Society of America 57 (1963), 222; G. Thomas Tanselle, "Whitman's Short Stories: Another Reprint," Papers of the Bibliographical Society of America 56 (1962), 115, hereafter, "Another Reprint"; see Myerson, A Descriptive Bibliography, 561. 
159 Tanselle, "Another Reprint," 115.

160 Brasher, EPF, 319n1.

161 Ibid., Appendix A, 338.

162 Ibid., Appendix A, 338.

163 Ibid., Appendix A, 338.

164 Ibid., Appendix A, 338.

165 Jerome Loving writes: "In 'The Little Minstrel Girl-A Tale of Truth,' a story Whitman could have written, the themes of temperance and patriotism are combined to tell a moralistic tale about a little street singer who charms the patrons of a tavern in Philadelphia” (105-106). See Loving, Song of Himself, 105-106. 